\title{
Article
}

\section{Fischer-Tropsch Diesel and Biofuels Exergy and Energy Analysis for Low Emissions Vehicles}

\author{
Felipe Andrade Torres ${ }^{1,2}{ }^{(}$, Omid Doustdar ${ }^{3}{ }^{(D)}$, Jose Martin Herreros ${ }^{3}{ }^{\circ}$, Runzhao Li $^{3}$, Robert Poku ${ }^{3}$, \\ Athanasios Tsolakis ${ }^{3, *}$, Jorge Martins ${ }^{4}(\mathbb{D})$ and Silvio A. B. Vieira de Melo ${ }^{1,5}(\mathbb{D}$ \\ 1 Industrial Engineering Program, Polytechnic School, Federal University of Bahia, Salvador 40210-630, Brazil; \\ ftorres@ufrb.edu.br (F.A.T.); sabvm@ufba.br (S.A.B.V.d.M.) \\ 2 Center of Exact and Technological Sciences, Department of Mechanical Systems, Federal University of \\ Recôncavo of Bahia, Cruz das Almas 44380-000, Brazil \\ 3 Department of Mechanical Engineering, School of Engineering, University of Birmingham, \\ Birmingham B15 2TT, UK; o.doustdar@bham.ac.uk (O.D.); j.herreros@bham.ac.uk (J.M.H.); \\ rx1834@student.bham.ac.uk (R.L.); rxp798@student.bham.ac.uk (R.P.) \\ 4 Department of Mechanical Engineering, University of Minho, 4800-058 Guimaraes, Portugal; \\ jmartins@dem.uminho.pt \\ 5 Interdisciplinary Center in Energy and Environment, Federal University of Bahia, Salvador 40170-115, Brazil \\ * Correspondence: a.tsolakis@bham.ac.uk
}

Citation: Torres, F.A.; Doustdar, O.; Herreros, J.M.; Li, R.; Poku, R.; Tsolakis, A.; Martins, J.; Vieira de Melo, S.A.B. Fischer-Tropsch Diesel and Biofuels Exergy and Energy Analysis for Low Emissions Vehicles. Appl. Sci. 2021, 11, 5958. https:// doi.org/10.3390/app11135958

Academic Editor: Adrian Irimescu

Received: 20 May 2021

Accepted: 24 June 2021

Published: 26 June 2021

Publisher's Note: MDPI stays neutral with regard to jurisdictional claims in published maps and institutional affiliations.

Copyright: (c) 2021 by the authors. Licensee MDPI, Basel, Switzerland. This article is an open access article distributed under the terms and conditions of the Creative Commons Attribution (CC BY) license (https:// creativecommons.org/licenses/by/ $4.0 /)$.

\begin{abstract}
This research investigates the effects of a synthetic diesel-like fuel (Fischer-Tropsch diesel) and biofuels (ethanol and biodiesel) fuel blends on the energy-exergy efficiencies and gaseous exhaust emissions characteristics of a compression ignition engine. Two blends of alternative fuels denoted as E15B35FTD50 (15\% ethanol, 35\% biodiesel, and 50\% Fischer-Tropsch diesel) and E15B35D50 (15\% ethanol, 35\% biodiesel, and 50\% diesel) were experimentally studied on a single-cylinder diesel engine and compared to diesel fuel. The results show that the energetic and the exergetic efficiencies of the alternative fuels are comparable to those of the engine fueled with diesel fuel. The unburnt $\mathrm{HC}$, $\mathrm{NO}, \mathrm{N}_{2} \mathrm{O}$, and $\mathrm{NH}_{3}$ emissions were reduced for the two alternative fuel blends compared to diesel, while $\mathrm{CO}$ emissions increased. The light $\mathrm{HC}$ species were found to slightly increase for the alternative fuel blends in comparison with diesel fuel. However, the total HC was considerably reduced by the combustion of E15B35FTD50 not only when compared to the diesel fuel combustion, but also when compared to E15B35D50. Overall, these results may contribute to identifying advantages and limitations in terms of energetic-exergetic analysis and emissions for the new generation of conventional diesel and hybrid electric vehicles that aim to achieve future emissions regulations.
\end{abstract}

Keywords: biofuels; energy; exergy; emissions; ethanol; Fischer-Tropsch diesel; engine

\section{Introduction}

Internal combustion engines (ICE) are the worldwide major powertrain system that enables road transportation. Although electric vehicles are gradually gaining inroads in the automotive market, ICE still continues to be widely used worldwide [1,2] both in ICE vehicles as well as in hybrid electric vehicles (HEV). Full electrification is still in the early stages of development in most countries. For example, in Brazil, hybrid and flexible-fuel vehicles are projected for the future with $52 \%$ and $32 \%$ contribution by 2050 , respectively. The electrification and biofuel synergies are required to enhance Brazil's capability for meeting the Paris Agreement targets [3].

Current legislation is forcing the reduction of exhaust emissions, particularly nitrogen oxides $\left(\mathrm{NO}_{\mathrm{x}}\right)$ and particulate matter $(\mathrm{PM})$ for compression ignition $(\mathrm{CI})$ engines. One of the alternatives to reduce engine exhaust emissions towards this effort is the use of alternative fuels $[4,5]$. Biofuels and hybrid electric vehicle synergies can effectively contribute to mitigating the dependence on fossil fuels as well as the greenhouse gases and air quality issues associated with their emissions. These synergies are not only applicable to the 
utilization of the fuel in the vehicle but also in a well-to-wheel system evaluation. This reinforces the renewable energy proposal, especially in countries where the electrical matrix is primarily renewable, such as the case of Brazil. Fischer-Tropsch (F-T) fuels, as one of the common biofuels, are synthetic fuels that can be produced from catalytic conversion processes using biomass (biomass-to-liquid or BTL) as raw materials that are able to be used to synthesize diesel-like fuels [6], among others. Therefore, the F-T diesel might be considered a renewable fuel depending on the type of raw material that was used to convert it into synthetic diesel-like fuel [7]. However, not usually used in diesel engines, ethanol is the most produced biofuel in the world and is another key biofuel that can be used as a fuel component in CI engines [8,9]. Biodiesel is a diesel-like fuel that can partially substitute the diesel fuel in a diesel engine. These alternative fuels can form binary and ternary fuel blends to be used in CI engines without requiring major powertrain modifications [10].

Researchers have investigated the use of biofuels in CI engines. Emiroğlu and Şen [11] evaluated diesel/biodiesel/alcohol fuel blends on a single-cylinder diesel engine. Increases in nitrogen oxides $\left(\mathrm{NO}_{\mathrm{x}}\right)$ and hydrocarbons $(\mathrm{HC})$ emissions, decrease in smoke, and carbon monoxide $(\mathrm{CO})$ were obtained compared to diesel fuel combustion. They also reported that the thermal (or energy) efficiencies of the engine were very similar when using biodiesel/alcohols or when using diesel fuel. Valencia Ochoa et al. [12] investigated two types of biodiesel blended with diesel fuel on a single-cylinder diesel engine. They reported that the blends had lower $\mathrm{CO}, \mathrm{HC}$, smoke, and carbon dioxide $\left(\mathrm{CO}_{2}\right)$, but the $\mathrm{NO}_{\mathrm{x}}$ emissions increased compared to diesel fuel engine operation. Additionally, the results showed that diesel fuel had the highest energy efficiency among the tested fuels. Choi et al. [13] assessed two blends of GTL (gas-to-liquid) and biodiesel on a single-cylinder diesel engine and compared them to pure GTL fuel. It is concluded that the GTL100 (100\% GTL fuel) exhibited lower $\mathrm{NO}_{x}, \mathrm{CO}, \mathrm{HC}$, and soot than the biodiesel blended with GTL fuel. Venu et al. [14] evaluated a ternary blend of diesel/biodiesel/ethanol with and without alumina $\left(\mathrm{Al}_{2} \mathrm{O}_{3}\right)$ nanoparticles on a single-cylinder diesel engine. It is reported that the ternary blend decreased the $\mathrm{CO}, \mathrm{HC}$, smoke, and $\mathrm{PM}$, although the $\mathrm{NO}_{\mathrm{x}}$ increased and the engine thermal efficiency was lower for the blend than for diesel fuel. Furthermore, studies showed a remarkable emission reduction with hybrid electric vehicles running with biofuels [15]. García et al. [16] investigated two advanced dual-fuel combustion modes using bioethanol as the main fuel for hybrid passenger vehicles, a pre-chamber ignition system (PCIS) using bioethanol and hydrogen, and reactivity-controlled compression ignition (RCCI) combustion mode fueled with bioethanol/diesel. As a result, the RCCI mode has shown the highest potential to decrease the $\mathrm{NO}_{x}$ emissions while presenting the highest benefits in energy consumption, however had penalties in terms of $\mathrm{CO}_{2}$ emissions. García et al. [17] also studied dual-fuel diesel and E85 (85\% ethanol and 15\% gasoline) in a series hybrid vehicle concept and concluded that ultra-low engine-out emissions could be achieved for $\mathrm{NO}_{x}$. Furthermore, regarding advanced combustion strategies, Kumar and Sandhu [18] recently reviewed the impact of partially premixed combustion (PPC) on CI engines and summarized that the integrated application of PPC mode in addition to high octane number fuels, such as ethanol and butanol, in modern CI engine is a promising key alternative to match the stringent emission legislation. Macián et al. [19] evaluated the potential of synthetic fuels towards the forthcoming EURO VII emissions limits. The researchers reported that the 2030 target to $\mathrm{CO}_{2}$ emissions could be achieved in a well-to-wheel base as well as they reached ultra-low $\mathrm{NO}_{\mathrm{x}}$ emissions $(<0.2 \mathrm{~g} / \mathrm{kWh})$ with zero-soot emissions through the engine operational map. However, they concluded that in order to reduce $\mathrm{CO}_{2}$ emissions and reduce fuel consumption, vehicle hybridization must be considered. Besides, the automotive industry is continuously developing diesel combustion system designs to achieve the $\mathrm{CO}_{2}$ targets and improve overall engine-out emissions [20].

Most of these works have evaluated the energetic analysis of alternative fuels in $\mathrm{CI}$ engines in terms of the First Law of Thermodynamics. This is the most frequently employed method, but solely it is not sufficient to establish the losses and the efficiency of a 
system [21]. Exergy analysis is a method that combines both the First and the Second Laws of Thermodynamics to determine the losses (or irreversibilities) of a system [22]. It helps in assessing the source of these losses and allows more detailed information regarding the efficiency of the engine. Besides, it is an important tool to provide the exergy destruction analysis of a system [23].

Table 1 shows a summary of the results of energy and exergy analysis of previously conducted investigations. It becomes clear that the exergy efficiency is of great interest to the scientific community, as it directly identifies the existing destructions during the engine operation process. It is well established by the literature that increasing the engine load leads to an increase in the energy and exergy efficiencies [24,25], whilst increasing the engine speed causes the opposite effect $[26,27]$. Therefore, a detailed analysis of the effects of a specific fuel or blend on the energetic and exergetic efficiencies could be performed by comparing the efficiencies and the losses of the engine.

Based on the aforementioned studies, this work contributes to the current literature by applying an energetic analysis (fuel energy, energy losses, outlet work, and energy efficiency) and exergetic analysis (fuel exergy, exergy losses, work outlet, irreversibilities, exergy destruction, exergy efficiency, entropy generation, and sustainable index) as well as the emissions characteristics of a diesel engine fueled with F-T diesel, ethanol, and biodiesel blends. To obtain a comprehensive comparison of the effects of combining F-T diesel and ethanol/biodiesel, the engine performance results were compared with the engine using diesel fuel, as baseline fuel. A steady engine condition was selected based on previous work of the research group [28].

Table 1. Summary of the energy and exergy results from other investigations.

\begin{tabular}{|c|c|c|c|c|c|c|c|}
\hline Ref. & Year & $\begin{array}{c}\text { Engine } \\
\text { Characteristics }\end{array}$ & $\begin{array}{l}\text { Operating } \\
\text { Conditions }\end{array}$ & Fuel Type & $\begin{array}{c}\text { Energy } \\
\text { Efficiency (\%) }\end{array}$ & $\begin{array}{c}\text { Exergy } \\
\text { Efficiency (\%) }\end{array}$ & Outcomes \\
\hline [26] & 2016 & $\begin{array}{l}\text { 1-cylinder } \\
4 \text { stroke } \\
\text { Antor 3LD510 }\end{array}$ & $\begin{array}{l}12 \text { different speeds } \\
\text { (1000-3000 rpm) } \\
\text { Full load }\end{array}$ & $\begin{array}{c}\text { Diesel } \\
\text { D75-92/B10-20/E5 }\end{array}$ & $\begin{array}{c}27.18-31.42 @ \\
1400 \mathrm{rpm} \\
24.13-27.62 @ \\
2800 \mathrm{rpm}\end{array}$ & $\begin{array}{l}25.37-29.34 @ \\
1400 \mathrm{rpm} \\
22.53-25.82 @ \\
2800 \mathrm{rpm}\end{array}$ & $\begin{array}{c}\uparrow \text { speed } \downarrow \text { efficiency } \\
\eta_{\text {diesel }}>\eta_{\text {blends }} \\
\psi_{\text {diesel }}>\psi_{\text {blends }}\end{array}$ \\
\hline [29] & 2016 & $\begin{array}{c}\text { 4-cylinders } \\
4 \text { stroke } \\
\text { OM } 314 \text { Euro II }\end{array}$ & $\begin{array}{l}5 \text { speeds } \\
5 \text { loads }\end{array}$ & $\begin{array}{c}\text { Diesel } \\
\text { D50-78/B0-40/E0-16 }\end{array}$ & $\mathrm{n} / \mathrm{a}$ & $\begin{array}{c}25.21-32.88 @ \\
40 \% \text { load } \\
31.68-24.20 @ \\
80 \% \text { load }\end{array}$ & $\begin{array}{c}\uparrow \text { speed } \downarrow \text { efficiency } \\
\uparrow \text { load } \uparrow \text { efficiency }\end{array}$ \\
\hline [30] & 2017 & $\begin{array}{c}\text { 1-cylinder } \\
4 \text { stroke } \\
\text { Kirloskar TV-1 }\end{array}$ & $\begin{array}{c}1500 \text { rpm } \\
6 \text { loads } \\
(20-120 \%)\end{array}$ & $\begin{array}{c}\text { Diesel } \\
\text { D30-45/B50/E5-20 }\end{array}$ & $\begin{array}{c}23.49-27.05 @ \\
80 \% \text { load } \\
25.33-32.19 @ \\
100 \% \text { load }\end{array}$ & $\begin{array}{c}\text { 20.91-24.49@ } \\
80 \% \text { load } \\
23.29-29.32 @ \\
100 \% \text { load }\end{array}$ & $\begin{array}{c}\uparrow \text { load } \uparrow \text { efficiency } \\
\eta_{D 35 / E 15 / B 50}>\eta_{\text {diesel }} \\
\psi_{D 35 / E 15 / B 50}>\psi_{\text {diesel }}\end{array}$ \\
\hline [31] & 2019 & $\begin{array}{l}\text { 4-cylinders } \\
4 \text { stroke } \\
\text { Yangdong Y85 }\end{array}$ & $\begin{array}{l}1600 \mathrm{rpm} \\
\text { Full load }\end{array}$ & $\begin{array}{c}\text { Diesel } \\
\text { D41-78/B17-49/E5- } \\
10\end{array}$ & $25.82-27.08$ & $\mathrm{n} / \mathrm{a}$ & $\eta_{\text {diesel }}>\eta_{\text {blends }}$ \\
\hline [32] & 2019 & $\begin{array}{c}\text { 1-cylinder } \\
4 \text { stroke } \\
\text { Kirloskar TAF1 }\end{array}$ & $\begin{array}{l}1500 \text { rpm } \\
5 \text { loads }\end{array}$ & $\begin{array}{c}\text { Diesel } \\
\text { D90-98/B1.5- } \\
\text { 7.5/E0.5-2.5 }\end{array}$ & $\begin{array}{l}19.25-21.24 @ \\
40 \% \text { load } \\
22.73-32.77 @ \\
\text { full load }\end{array}$ & $\begin{array}{l}21.45-28.21 @ \\
\quad \text { full load }\end{array}$ & $\begin{array}{c}\uparrow \text { load } \uparrow \text { efficiency } \\
\eta_{D 90 / B 7.5 / E 2.5}>\eta_{\text {diesel }} \\
\psi_{\text {D90/B7.5/E2.5 }}>\psi_{\text {diesel }}\end{array}$ \\
\hline [33] & 2020 & $\begin{array}{c}\text { 6-cylinders } \\
4 \text { stroke } \\
\text { Scania DC } 1102\end{array}$ & $\begin{array}{l}1450 \mathrm{rpm} \\
5 \text { loads } \\
(3-92 \%)\end{array}$ & $\begin{array}{c}\text { GTL } \\
\text { GTL25-75/B25-75 }\end{array}$ & $\begin{array}{c}14.65-15.05 @ \\
3 \% \text { load } \\
43.93-45.27 @ \\
92 \% \text { load }\end{array}$ & $\begin{array}{c}13.70-14.08 @ \\
3 \% \text { load } \\
41.12-41.65 @ \\
92 \% \text { load }\end{array}$ & $\begin{array}{l}\uparrow \text { load } \uparrow \text { efficiency } \\
\eta_{G T L 25 / B 75}>\eta_{\mathrm{GTL}} \\
\psi_{\mathrm{GTL} 25 / B 75}>\psi_{\mathrm{GTL}}\end{array}$ \\
\hline [34] & 2020 & $\begin{array}{l}\text { 1-cylinder } \\
4 \text { stroke } \\
\text { NSB-8.18 }\end{array}$ & $\begin{array}{l}1900 \mathrm{rpm} \\
2 \text { loads }\end{array}$ & $\begin{array}{c}\text { Diesel } \\
\text { D82/B10/E8 }\end{array}$ & $\begin{array}{c}21.9-22.0 @ \\
5.71 \mathrm{~kW} \\
22.6-22.9 @ \\
7.43 \mathrm{~kW}\end{array}$ & $\mathrm{n} / \mathrm{a}$ & $\begin{array}{c}\uparrow \text { load } \uparrow \text { efficiency } \\
\eta_{\text {diesel }}>\eta_{\mathrm{D} 82 / \mathrm{B} 10 / \mathrm{E} 8}\end{array}$ \\
\hline [27] & 2020 & $\begin{array}{l}\text { 1-cylinder } \\
4 \text { stroke }\end{array}$ & $\begin{array}{l}2 \text { speeds } \\
\text { Full load }\end{array}$ & $\begin{array}{c}\text { Diesel } \\
\text { D60-75/B20/But5-20 }\end{array}$ & $\begin{array}{c}30.17-31.92 @ \\
1400 \mathrm{rpm} \\
26.91-27.83 @ \\
2800 \mathrm{rpm}\end{array}$ & $\begin{array}{l}28.13-29.77 @ \\
1400 \mathrm{rpm} \\
25.03-25.96 @ \\
2800 \mathrm{rpm}\end{array}$ & $\begin{array}{c}\uparrow \text { speed } \downarrow \text { efficiency } \\
\eta_{\text {diesel }}>\eta_{\text {blends }} \\
\psi_{\text {diesel }}>\psi_{\text {blends }}\end{array}$ \\
\hline
\end{tabular}




\section{Materials and Methods}

\subsection{Experimental Setup}

The simplified schematic diagram of the experimental setup is shown in Figure 1. A common-rail single-cylinder direct injection diesel engine, four-stroke, water-cooled, with $84 \mathrm{~mm} \times 90 \mathrm{~mm}$ of the cylinder bore and stroke respectively, connecting rod length of $160 \mathrm{~mm}, 16: 1$ of compression ratio, and a displacement of $499 \mathrm{~cm}^{3}$ was used for this research. The fuel injection pressure could be set in the interval 500-1500 bar and the maximum indicated mean effective pressure (IMEP) could go up to 7 bar. An electric dynamometer was coupled to the engine, enabling the braking and the motoring of the engine.

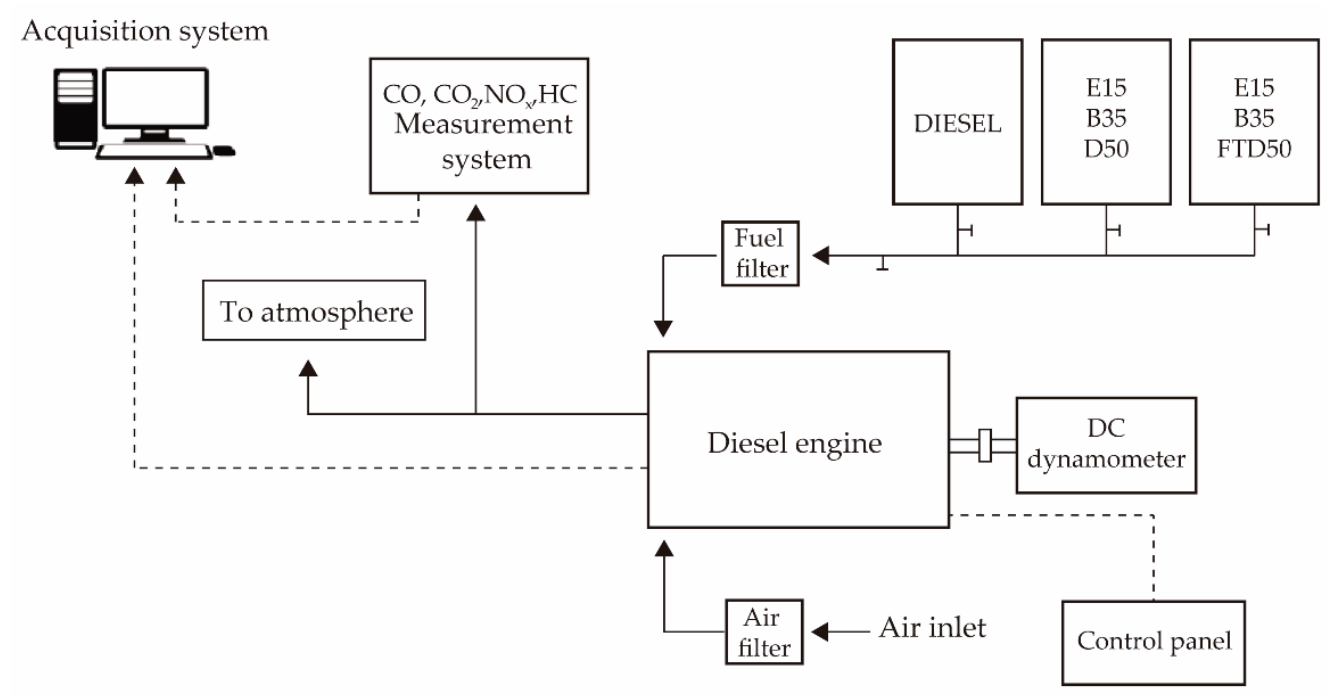

Figure 1. Schematic diagram of the experimental setup.

The fuels were tested with the engine kept at a steady-state condition of 2 bar IMEP, representing around $30 \%$ of the maximum load, and an engine speed of $1500 \mathrm{rpm}$. Before the test, the engine was warmed up to minimize the effects of emission variation during the engine cold-start. The IMEP was continuously monitored in order to keep a constant engine IMEP condition as the baseline fuel. All fuels were injected into the combustion chamber at 550 bar and two injection stages, divided into the pilot $\left(15^{\circ}\right.$ before the top dead center, bTDC) and main ( $\left.5^{\circ} \mathrm{bTDC}\right)$ injection. The pilot injection duration was kept constant $(0.150 \mathrm{~ms})$, but the main injection was adjusted during the change of fuels. Therefore, during shifting fuels, an adjustment of the main injection duration was necessary $(0.499$, 0.529 , and $0.546 \mathrm{~ms}$, respectively for Diesel, E15B35D50, and E15B35FTD50).

Shell Global Solutions UK provided the ultra-low sulfur diesel fuel ( $<10 \mathrm{ppm}$ sulfur $)$ and the Fischer-Tropsch diesel. The ethanol was supplied by Fisher Scientific Company with a purity of $99.8 \%$. The biodiesel was purchased from Egogas Ltd. (Kidderminster, UK) and the composition consisted of approximately $90 \%$ rapeseed methyl ester and $10 \%(v / v)$ palm oil methyl ester. The blends were prepared at the University of Birmingham and the physical and chemical properties of all fuels were calculated or obtained from the respective suppliers or publications [35,36], as shown in Table 2. Particularly, the diesel fuel that was used as a reference in this work was selected without any biodiesel in the composition (no oxygen content). The blends were prepared by mixing ethanol and biodiesel in the same volumetric proportion (15\% of ethanol and 35\% of biodiesel) with 50\% F-T diesel (E15B35FTD50) and also with 50\% diesel fuel (E15B35D50). Moreover, both fuel blends had the same oxygen content, and hence the influence of the oxygen when F-T diesel was blended with ethanol and biodiesel could be investigated. 
Table 2. Physical and chemical properties of the fuels.

\begin{tabular}{|c|c|c|c|c|c|c|}
\hline \multicolumn{3}{|c|}{ Abbreviation } & \multicolumn{4}{|c|}{$\%$ Volumetric Make-Up } \\
\hline \multirow{3}{*}{\multicolumn{3}{|c|}{$\begin{array}{c}\text { Diesel } \\
\text { E15B35D50 } \\
\text { E15B35FTD50 }\end{array}$}} & \multirow{3}{*}{\multicolumn{4}{|c|}{$\begin{array}{c}100 \text { diesel } \\
15 \text { ethanol }+35 \text { biodiesel }+50 \text { diesel } \\
15 \text { ethanol }+35 \text { biodiesel }+50 \text { F-T diesel }\end{array}$}} \\
\hline & & & & & & \\
\hline & & & & & & \\
\hline Properties & Diesel & Ethanol & Biodiesel & F-T Diesel & E15B35D50 & E15B35FTD50 \\
\hline Chemical formula & $\mathrm{C}_{14} \mathrm{H}_{26.1}$ & $\mathrm{C}_{2} \mathrm{H}_{5} \mathrm{OH}$ & $\mathrm{C}_{19} \mathrm{H}_{35.3} \mathrm{O}_{2}$ & $\mathrm{C}_{16.89} \mathrm{H}_{35.77}$ & $\mathrm{C}_{14.13} \mathrm{H}_{26.88} \mathrm{O}_{1.21}$ & $\mathrm{C}_{15.52} \mathrm{H}_{31.53} \mathrm{O}_{1.24}$ \\
\hline Cetane number & 53.9 & 8 & 54.7 & 79 & $47.7^{(\mathrm{a})}$ & $59.6^{\mathrm{a}}$ \\
\hline Heat of vaporization $[\mathrm{kJ} / \mathrm{kg}]$ & 243 & 858 & 216 & 339 [37] & $\mathrm{n} / \mathrm{a}$ & $\mathrm{n} / \mathrm{a}$ \\
\hline Lower heating value $[\mathrm{MJ} / \mathrm{kg}]$ & 43.11 & 26.83 & 37.8 & 43.90 & $38.86^{\mathrm{a}}$ & $39.13^{\mathrm{a}}$ \\
\hline Density at $15^{\circ} \mathrm{C}\left[\mathrm{kg} / \mathrm{m}^{3}\right]$ & 827.1 & 789.4 & 883.7 & 784.6 & $841.26^{b}$ & $820.01^{b}$ \\
\hline Aromatics [wt \%] & 24.4 & 0 & $\sim 0$ & 0.3 & $\mathrm{n} / \mathrm{a}$ & $\mathrm{n} / \mathrm{a}$ \\
\hline Theoretical A-F ratio & 14.56: 1 & 10.33: 1 & 11.77: 1 & 14.91: 1 & 12.92: 1 & 13.20: 1 \\
\hline $\mathrm{C} / \mathrm{H}$ ratio & 6.41 & 3.97 & 6.43 & 5.67 & 6.02 & 5.65 \\
\hline Carbon content [wt \%] & 86.47 & 52.14 & 77.15 & 84.91 & 78.06 & 77.28 \\
\hline Hydrogen content [wt \%] & 13.53 & 13.13 & 12.03 & 15.09 & 12.94 & 13.72 \\
\hline Oxygen content [wt \%] & 0 & 34.73 & 10.82 & 0 & 9.0 & 9.0 \\
\hline
\end{tabular}

n/a: not available ${ }^{a}$ Estimated based on the mass fraction for each component [38]. ${ }^{b}$ Estimated based on the volumetric fraction for each component [38].

The $\mathrm{O}_{2}$ emissions were measured using Testo 340 gas analyzer while the gaseous emissions of $\mathrm{CO}, \mathrm{CO}_{2}, \mathrm{NO}_{\mathrm{x}}\left(\mathrm{NO}\right.$ and $\left.\mathrm{NO}_{2}\right)$, nitrous oxide $\left(\mathrm{N}_{2} \mathrm{O}\right)$, ammonia $\left(\mathrm{NH}_{3}\right)$, formaldehyde $\left(\mathrm{CH}_{2} \mathrm{O}\right)$, total $\mathrm{HC}$ (sum of heavy and other unburned hydrocarbons), and individual light hydrocarbons species including methane $\left(\mathrm{CH}_{4}\right)$, ethane $\left(\mathrm{C}_{2} \mathrm{H}_{6}\right)$, acetylene $\left(\mathrm{C}_{2} \mathrm{H}_{2}\right)$, ethylene $\left(\mathrm{C}_{2} \mathrm{H}_{4}\right)$, propane $\left(\mathrm{C}_{3} \mathrm{H}_{8}\right)$, and propylene $\left(\mathrm{C}_{3} \mathrm{H}_{6}\right)$ were measured using an MKS MultiGas 2030 based on FTIR (Fourier Transform Infrared Spectroscopy) technique. For the calculation of the total hydrocarbons species, the corresponding flame ionization detector (FID) response factors were contained from the FTIR raw file and implemented for each individual $\mathrm{HC}$ reading as follows: $\mathrm{THC}=(1.1 \times$ methane $)+(2.4 \times$ acetylene $)+(1.9 \times$ ethylene $)+(2 \times$ ethane $)+(2.85 \times$ propylene $)+(1.35 \times$ heavy HC $)$ [39]. The exhaust gas sampling system of the emission analyzer was maintained at a constant temperature of $191{ }^{\circ} \mathrm{C}$ by using a heated sampling line to prevent moisture and condensation during the sampling. The main technical characteristics and measurement accuracies are shown in Table 3.

Table 3. Accuracy of the equipment used in this work.

\begin{tabular}{cccc}
\hline Measure & Instrument & Range & $\begin{array}{c}\text { Accuracy of the } \\
\text { Measurement Range }\end{array}$ \\
\hline Exhaust gas $\left(\mathrm{CO}, \mathrm{CO}_{2}, \mathrm{NO}_{\mathrm{x}}, \mathrm{THC}\right)$ & Multigas 2030 FTIR & $10 \mathrm{ppb}-100 \%$ full scale & $\pm 5 \%$ \\
Exhaust gas $\left(\mathrm{O}_{2}\right)$ & Testo 340 & $0-25 \%$ & $\pm 0.2 \%$ \\
Crank angle, engine speed & Digital shaft encoder & - & $\pm 1 \mathrm{rev} / \mathrm{min}$ \\
In-cylinder pressure & AVL GH13P pressure sensor & $0-250 \mathrm{bar}$ & $\pm 1 \%$ \\
Temperature & K-type thermocouples & of $0-1250{ }^{\circ} \mathrm{C}$ & $\pm 2.2{ }^{\circ} \mathrm{C}$ \\
\hline
\end{tabular}

The engine was warmed up to minimize the effects of exhaust emission variation during the engine cold-start. Before the substitution between fuels, the fuel tanks and injection systems were cleaned. After this, the engine was kept constant for 30 min with the new fuel. The fuel consumption was measured in triplicate to obtain an average value. The FTIR measurements were recorded for $20 \mathrm{~min}$ to ensure reliability, while the Testo values were an average of two readings. Later, the experimental uncertainty has been calculated and error bars have been included in all the figures. 


\subsection{Thermodynamic Analysis}

The control volume of the thermodynamic system is given in Figure 2, including the inlet and outlet terms. The equations used to calculate the inlet and outlet energy and exergy rates follow the literature [40-43]. The first and second laws of thermodynamics were applied to this system with the following assumptions:

- The engine operation is studied at the steady-state condition;

- The intake air and the outlet exhaust gases were considered as mixtures of ideal gases;

- The environment (reference state) was considered at $\mathrm{T}_{0}=25^{\circ} \mathrm{C}$ and $\mathrm{P}_{0}=101.325 \mathrm{kPa}$ and did not vary with time;

- The kinetic and potential energy effects of incoming fluid streams and outgoing fluid streams were neglected [44].

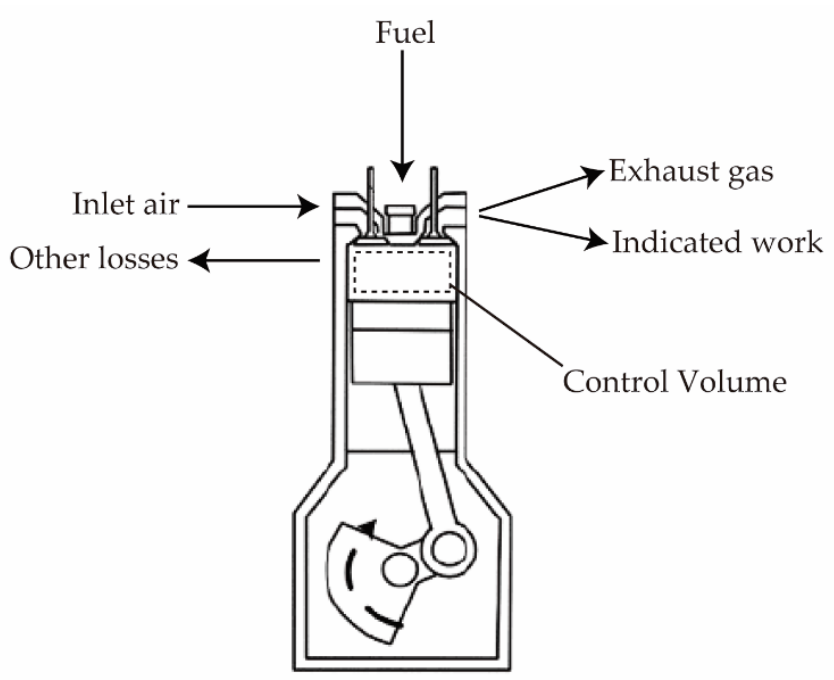

Figure 2. Control volume of the engine.

\subsubsection{Energy Analysis}

Based on the assumptions made, the mass and energy balances of the control volume are given by Equations (1)-(3) below:

$$
\begin{gathered}
\sum \dot{m}_{\text {in }}=\sum \dot{m}_{\text {out }} \\
\sum \dot{E} n_{\text {in }}=\sum \dot{E} n_{\text {out }} \\
\dot{E} n_{\text {air }}+\dot{E} n_{\text {fuel }}=\dot{E} n_{W}+\dot{E} n_{\text {exh }}+\dot{E} n_{\text {loss }}
\end{gathered}
$$

where $\dot{m}_{\text {in }}$ and $\dot{m}_{\text {out }}$ are respectively the inlet and outlet mass flow rates, $\sum \dot{E} n_{\text {in }}$ and $\sum \dot{E} n_{\text {out }}$ represents respectively the total energy inlet and outlet rates of the control volume, $\dot{E} n_{\text {air }}$ is the inlet energy rate of air, $\dot{E} n_{f u e l}$ is the inlet energy rate of the fuel, $\dot{E} n_{W}$ is the energy rate by work, $\dot{E} n_{\text {exh }}$ is the energy outlet rate by the exhaust, and $\dot{E} n_{\text {loss }}$ is the energy loss rate of the control volume. Because the intake air stream is at the same temperature as the reference state, the amount of energy inlet into the control volume can be neglected [45].

The rate of energy inlet from the fuel $\left(\dot{E} n_{f u e l}\right)$ to the control volume is calculated using the fuel mass flow $\left(\dot{m}_{\text {fuel }}\right)$ and the fuel lower heating value (LHV) as shown in Equation (4) below, where $i$ represents the different fuels that composed the blend.

$$
\dot{E} n_{f u e l}=\sum_{i=1}^{3} \dot{m}_{f u e l} \cdot L H V_{f_{u e l}}
$$


The work rate $\left(\dot{E} n_{W}\right)$ was considered as the indicated power of the engine, which is expressed by Equation (5) below:

$$
\dot{E} n_{W}=\frac{I M E P \cdot V_{d} \cdot N}{n_{R} \cdot 60 \cdot 10^{3}}
$$

where $N(\mathrm{rpm})$ is the engine speed, $V_{d}\left(\mathrm{~m}^{3}\right)$ represents the displaced volume, IMEP is the indicated mean effective pressure and $n_{R}$ is the number of crank revolutions for each power stroke per cylinder (e.g., $n_{R}$ is 2 for a four-stroke engine). The IMEP is calculated only from the cylinder pressure to represent the average pressure over a cycle of the engine.

The outlet exhaust energy rate $\left(\dot{E} n_{e x h}\right)$ of the control volume is determined as in Equation (6):

$$
\dot{E} n_{\text {exh }}=\sum_{i} \dot{m}_{i} \cdot h_{i}
$$

where $\dot{m}_{i}$ is the mass flow rate and $h_{i}$ is the enthalpy of each gaseous species in the engine exhaust, respectively.

Then, the energy loss rate ( $\left.\dot{E} n_{\text {loss }}\right)$ of the control volume consists of all energy heat losses involved, which includes the heat transfers from cylinder walls (combustion chamber and piston), by coolant, and by the oil, except for the exhaust losses. In this work, the $\dot{E} n_{\text {loss }}$ is calculated as the difference between the energy inlet rate and the energy outlet rate (work and exhaust gases) from the control volume, such as in [26,46], as shown in Equation (7) below:

$$
\dot{E} n_{\text {loss }}=\dot{E} n_{f u e l}-\dot{E} n_{W}+\dot{E} n_{\text {exh }}
$$

Finally, the energy efficiency $(\eta)$ of the control volume, based on the First Law of Thermodynamics (i.e., thermal efficiency), is defined as the work outlet ratio to the fuel energy inlet is shown in Equation (8).

$$
\eta=\frac{\dot{E} n_{W}}{\dot{E} n_{f u e l}}
$$

\subsubsection{Exergy Analysis}

Similar to the case of the energy analysis, the same assumptions were valid for the exergy analysis of the control volume. The exergy balance can be expressed as Equation (9) as follows:

$$
\begin{gathered}
\sum \dot{E} x_{i n}=\sum \dot{E} x_{\text {out }}+\dot{E} x_{\text {dest }} \\
\dot{E} x_{\text {air }}+\dot{E} x_{\text {fuel }}=\dot{E} x_{W}+\dot{E} x_{\text {exh }}+\dot{E} x_{\text {loss }}+\dot{E} x_{\text {dest }}
\end{gathered}
$$

where $\sum \dot{E} x_{\text {in }}, \sum \dot{E} x_{\text {out }}$ and $\dot{E} x_{\text {dest }}$ represents respectively, the total exergy inlet and outlet rates and the exergy destruction (irreversibility) rate of the control volume. $\dot{E} x_{a i r}$ is the inlet exergy rate of air, $\dot{E} x_{f u e l}$ is the inlet exergy rate from the fuel, $\dot{E} x_{W}$ is the exergy rate by work, $\dot{E} x_{\text {exh }}$ is the exergy outlet rate by the exhaust, and $\dot{E} x_{\text {loss }}$ is the exergy loss rate of the control volume. An equivalent assumption was considered for the air inlet rate, and by considering the environmental atmosphere as a reference state, the exergy associated with naturally aspirated air into the engine control volume is zero [47].

The inlet exergy rate from the fuel $\left(\dot{E} x_{f u e l}\right)$ to the control volume can be determined as follows in Equation (11), where $i$ represents the different fuels that composed the blend.

$$
\dot{E} x_{f u e l}=\sum_{i=1}^{3} \dot{m}_{f_{u l e} l_{i}} \cdot e x_{f_{u e l}}=\dot{m}_{\text {fuel }_{i}} \cdot L H V_{\text {fuel }_{i}} \cdot \varphi_{\text {fuel }_{i}}
$$

where $e x_{f u e l}$ is the fuel-specific exergy of the fuel, which can be obtained by multiplying the fuel lower heating value by the chemical exergy factor $(\varphi)$ of each fuel, which can be 
obtained through Equation (12) as in [41,42] for liquid fuels. The accuracy of this expression is estimated to be $\pm 0.38 \%$.

$$
\varphi=1.0401+0.1728 \frac{h}{c}+0.0432 \frac{o}{c}+0.2169 \frac{s}{c}\left(1-2.0628 \frac{h}{c}\right)
$$

where $h, c, o$, and $s$ are respectively the mass fractions of hydrogen, oxygen, carbon, and sulfur of the fuel $[41,42]$.

The exergy work rate $\left(\dot{E} x_{W}\right)$ is equal to the energy work rate of the control volume, as shown in Equation (13).

$$
\dot{E} x_{W}=\dot{E} n_{W}
$$

The exergy rate of exhaust gases $\left(\dot{E} x_{e x h}\right)$ is composed of two components that are the physical (thermomechanical) and chemical exergies, which is expressed in Equation (14).

$$
\dot{E} x_{e x h}=\sum_{i} \dot{n}_{i}\left(e x_{p h, i}+e x_{c h, i}\right)
$$

where $\dot{n}_{i}$ is the molar flow rate of each exhaust gas species, $e x_{p h, i}$ and $e x_{c h, i}$ are the specific physical and chemical exergies of each exhaust gas species, respectively.

For a mass flow that goes through the volume control, the specific physical exergy rate $\left(e x_{p h, i}\right)$ of the exhaust gas species is obtained by Equation (15) below.

$$
e x_{p h, i}=\left(h_{i}-h_{0}\right)-T_{0} \cdot\left(s_{i}-s_{0}\right)
$$

where $s_{i}$ is the entropy of each gaseous species in the engine exhaust.

For a gas mixture, the chemical exergy rate $\left(e x_{c h, i}\right)$ of the exhaust gas species can be calculated using Equation (16) as follow.

$$
e x_{c h, i}=\sum_{i} x_{i} \cdot \varepsilon_{c h, i}+R \cdot T_{0} \cdot \sum_{i}\left(x_{i} \cdot \ln \gamma_{i} \cdot x_{i}\right)
$$

where $x_{i}$ is the molar fraction of each species of the exhaust gas, $\varepsilon_{c h, i}$ is the standard chemical exergy [41,42], $\mathrm{R}$ is the universal gas constant $(8.314 \mathrm{~kJ} / \mathrm{kmol} \cdot \mathrm{K})$ and $\gamma_{i}$ is the activity coefficient ( $\gamma_{i}=1$ for ideal gases).

The exergy loss rate ( $\left.\dot{E} x_{\text {loss }}\right)$ shown in Equation (17) is considered to be the amount of exergy loss from the control volume, and the lost-exergy rate was assumed to be all heat losses occurring from the measured coolant temperature $\left(T_{\text {cool }}=353.15 \mathrm{~K}\right)$ to the environment at reference state temperature, as in $[29,48]$.

$$
\dot{E} x_{\text {loss }}=\sum\left(1-\frac{T_{0}}{T_{\text {cool }}}\right) \dot{E} n_{\text {loss }}
$$

Hence, the exergy destruction $\left(\dot{E} x_{\text {dest }}\right)$ is obtained from the exergy balance by Equation (18).

$$
\dot{E} x_{\text {dest }}=\dot{E} x_{f u e l}-\dot{E} x_{W}-\dot{E} x_{e x h}-\dot{E} x_{\text {loss }}
$$

Finally, the exergy efficiency $(\psi)$ of the control volume is presented in Equation (19) as follows.

$$
\psi=\frac{\dot{E} x_{W}}{\dot{E} x_{f u e l}}
$$

The entropy generation rate $\left(\dot{S}_{g e n}\right)$ is determined from the equation for the exergy destruction and is represented in Equation (20).

$$
\dot{S}_{g e n}=\frac{\dot{E} x_{\text {dest }}}{T_{0}}
$$


The sustainability index (SI) is a function of exergy efficiency and is one of the methods to assess the sustainability of a system and measures its environmental impact and economics of energy technologies or resources, showing the effects of changing the exergy efficiency of a process. The SI has a key role in understanding the sustainable usage of fuel energy resources when dealing with the assessment of the system $[25,27]$. Thus, the SI can be calculated by Equation (21), as given in [49]. This relation shows how sustainability is affected by changing the exergy efficiency of a process.

$$
S I=\frac{1}{1-\psi}
$$

\section{Results and Discussions}

\subsection{Gaseous Emissions}

The exhaust gaseous emissions results are shown in Figure 3. The overall lambda (i.e., actual air/fuel ratio over the stoichiometric air/fuel ratio) was found to be similar for the tested fuels as 2.9, 2.84, and 2.82 for diesel, E15B35D50, and E15B35FTD50, respectively. This is an indication that the difference between the fuels was the direct result of the fuel composition. The CO emissions with E15B35FTD50 and E15B35D50 increased compared to the reference fuel for the test condition. This could be a reflection of incomplete combustion occurring during the combustion process. In-cylinder pressure and detailed analysis of E15B35FTD50 and E15B35D50 fuel blends combustion process was reported in a previous work [50]. The lower combustion temperature due to the higher heat of vaporization of the ethanol is among the factors that might have influenced the higher $\mathrm{CO}$ results. Thus, the cooling effect of the alcohol dominates the effect of the total oxygen content of the blend of fuels, which might suppress the $\mathrm{CO}$ oxidation process [51]. Moreover, the lower cetane number of ethanol increases the time for ignition (longer ignition delay) of the air-fuel mixture [52]. Further, the higher viscosity of biodiesel has been indicated to promote poor atomization and hence increases $\mathrm{CO}$ emissions [53]. A recent study has reported that blends of F-T diesel and biodiesel resulted in slightly higher $\mathrm{CO}$ emission and the researchers attributed this to the insufficient evaporation and short mixing time of the blend during premixed combustion [13]. The application of a diesel oxidation catalyst could effectively reduce these $\mathrm{CO}$ levels from the combustion of these alternative fuels [50].

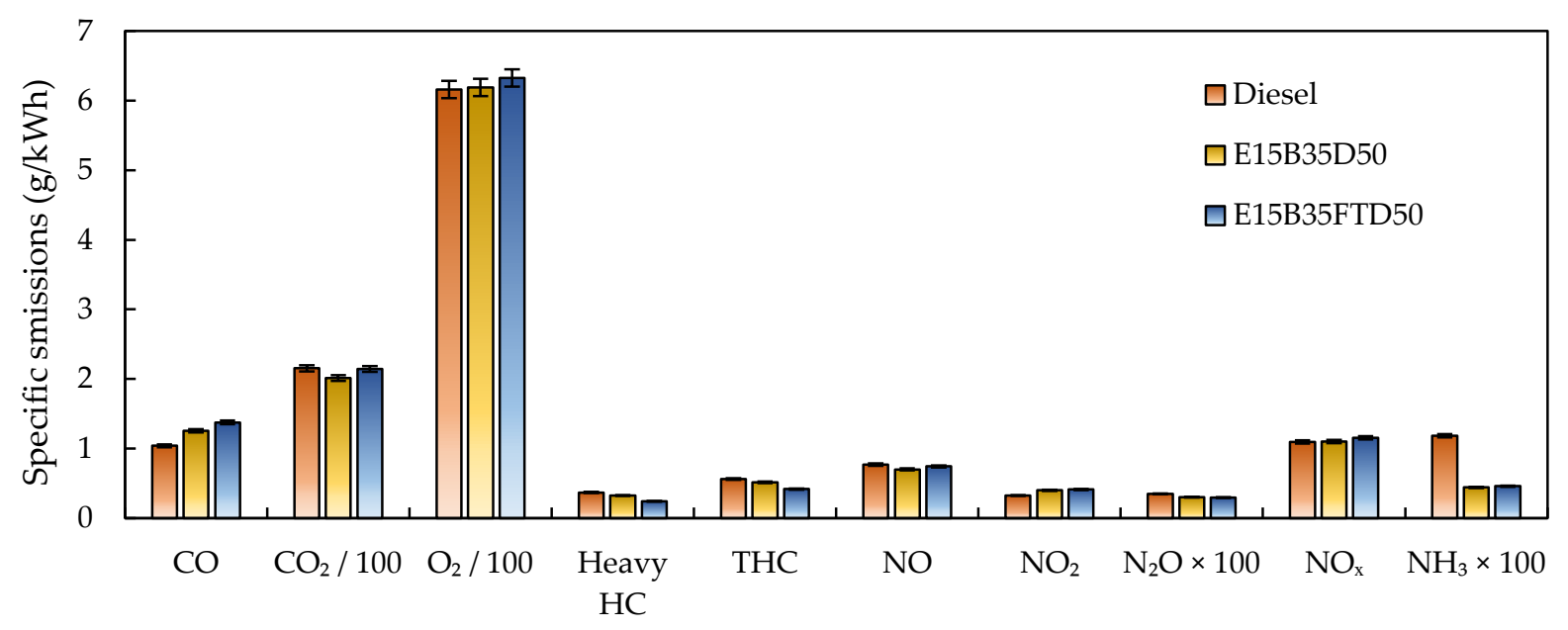

Figure 3. Exhaust gaseous emissions of diesel, E15B35D50, and E15B35FTD50.

A slight decrease in $\mathrm{CO}_{2}$ emissions was observed when the engine was fueled with E15B35D50, while $\mathrm{CO}_{2}$ emissions for E15B35FTD50 are slightly higher than in the case of diesel fuel. This is in line with the carbon content of the estimated chemical formula of the fuel blends, though it has to be noted that the differences are within the confidence interval of the results. $\mathrm{CO}_{2}$ is a common product of the combustion of hydrocarbon fuels so the 
lower carbon content of ethanol molecules leads to lower $\mathrm{CO}_{2}$ formation, even on an energy basis $\left(\mathrm{g}_{\mathrm{CO}_{2}} / \mathrm{MJ}_{\mathrm{fuel}}\right)$. In addition, for combustion stoichiometry, previous studies reported that an increase in $\mathrm{CO}_{2}$ emission with the addition of biofuels (ethanol and biodiesel) is attributed to the higher oxygen content of the oxygenated, which favors the combustion process and hence increases $\mathrm{CO}_{2}$ formation [54,55].

The combustion of E15B35D50 and E15B35FTD50 have reduced the THC emissions (mostly comprised of heavy unburned hydrocarbons) when compared to diesel fuel (Figure 3). It has been reported in the literature that ethanol and biodiesel addition to diesel blends increase [56] or decrease [14] the hydrocarbons emission. The total and the heavy hydrocarbons presented in the THC have decreased between 18-33\% for E15B35FTD50 in comparison with diesel or E15B35D50. This might be associated with the higher cetane number and the absence of aromatics of F-T diesel, contributing to the reduction in THC. Khan et al. [57] discussed that a higher cetane number and lower aromatic content are the main reasons for the occurrence of a shorter ignition delay time. Moreover, the virtually zero sulfur as well as the absence of aromatics, have been mentioned to result in a reduction in the engine-out exhaust emissions (i.e., reduce HC development and lowering PM) [58]. It has been previously reported in the literature that F-T diesel reduces hydrocarbons emissions [59] in comparison with diesel fuel. In this work, the addition of the oxygenated biofuels (ethanol and biodiesel) further reduced the unburned hydrocarbons emissions (Figure 3).

The light-saturated HC (methane and ethane) and the unsaturated HC (acetylene, ethylene, and propylene) species, shown in Figure 4, have been separately analyzed from the heavy HC in order to provide an in-depth analysis of the THC. The heavy hydrocarbons solely correspond to approximately $88 \%, 85 \%$, and 78\% of THC for diesel, E15B35D50, and E15B35FTD50, respectively. The decrease in the heavy HC (seen in Figure 3) follows the same trend for the blends as with the THC. On the other hand, higher emissions of the light HC species (saturated and unsaturated) were measured for the E15B35FTD50 and E15B35D50 as compared to diesel fuel. This result could be attributed to the thermal decomposition of the alcohol component of the blends into shorter molecules of HC (i.e., light HC species) and CO, as discussed by Fayad et al. [28]. Nevertheless, the combustion of diesel is likely to produce heavier HC, which supports the reduction of the THC for the blends.

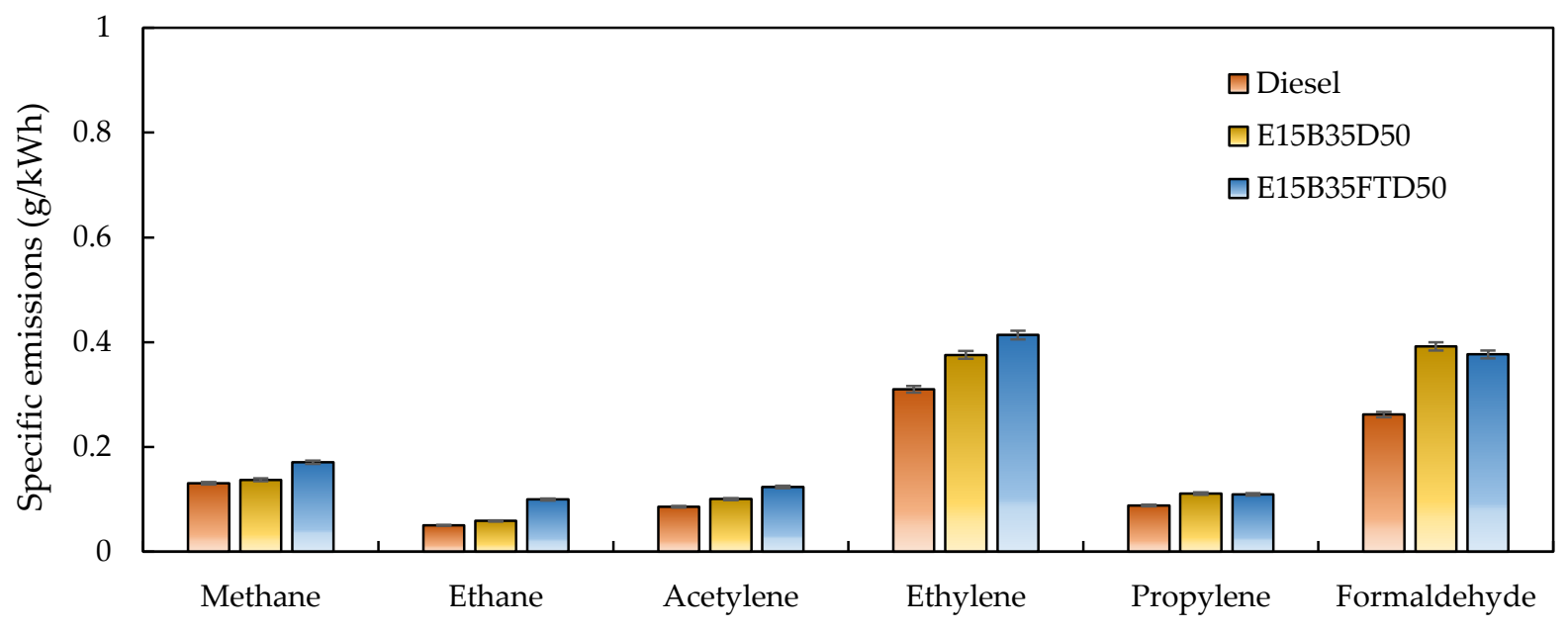

Figure 4. HC speciation for diesel, E15B35D50, and E15B35FTD50.

It was observed that the $\mathrm{NO}$ emissions have decreased around $2 \%$ and $8 \%$ respectively for E15B35FTD50 and E15B35D50 blends in comparison to diesel fuel. However, the $\mathrm{NO}_{2}$ emissions increased for these blends, which resulted in a similar or slight increase in the $\mathrm{NO}_{\mathrm{x}}$. The $\mathrm{NO}_{\mathrm{x}}$ emissions are directly dependent on high combustion temperatures, and thus ethanol could reduce the $\mathrm{NO}_{x}$ formation as a result of its high heat of evaporation 
that reduces the in-cylinder temperatures. Besides, it has been previously reported by Ye et al. [60] that F-T diesel decreases $\mathrm{NO}_{x}$ emissions in comparison with diesel fuel. However, the present work results have shown a slight increase in $\mathrm{NO}_{\mathrm{x}}$ emissions (4-5\%) with the use of the E15B35FTD50 blend in comparison with diesel and E15B35D50 blend (Figure 3). This is probably due to the biodiesel addition, which increased the oxygen content of the blend and may contribute to increasing the combustion temperature and thereby providing additional oxygen for $\mathrm{NO}_{x}$ formation. Similar results with oxygenated biofuels (ethanol and biodiesel) have been reported in the literature [61,62]. In addition to the oxygen content of the blend, the lower cetane number of the ethanol leads to an increase in the ignition delay, which increases the heat release rate during the combustion process because of the higher fuel amount in the combustion chamber [63]. Hence the $\mathrm{NO}_{\mathrm{x}}$ emission increases, as previously discussed by Emiroğlu and Şen [11]. The $\mathrm{N}_{2} \mathrm{O}$, which is not usually taken into account in the $\mathrm{NO}_{x}$ emissions, was also measured. The emissions of $\mathrm{N}_{2} \mathrm{O}$ have decreased around 13\% for both E15B35FTD50 and E15B35D50 blends when compared to diesel fuel. It is known that $\mathrm{N}_{2} \mathrm{O}$ is a harmful greenhouse gas promoter and also one of those responsible for ozone destruction [64]. The exhaust emissions result also includes $\mathrm{NH} 3$, another nitrogen compound. It was observed that the $\mathrm{NH}_{3}$ emissions reduced nearly $60 \%$ in the combustion of E15B35FTD60 and E15B35D50 with respect to diesel. NH3 is a precursor to secondary inorganic PM formation and secondary inorganic aerosol (i.e., $\mathrm{NH}_{4} \mathrm{NO}_{3}$, ammonium nitrate, and, $\left(\mathrm{NH}_{4}\right)_{2} \mathrm{SO}_{4}$, ammonia sulfate) [65].

\subsection{Energy Analysis}

To evaluate the effects of the fuel type on the energetic performance of the engine, the inlet and outlet energy fractions (work energy flow rate, exhaust gases energy flow rate, and energy losses flow rate) were calculated by dividing each energy component by the energy of the fuel, as shown in Table 4. During the tests, the IMEP was kept constant whereas the fuel flow variated.

Table 4. Energy distribution in the engine control volume.

\begin{tabular}{ccccc}
\hline Fuel & Fuel Energy Rate $\mathbf{( k W )}$ & Work Rate $\mathbf{( k W )}$ & Exhaust Gas Energy Rate (kW) & Heat Losses Rate (kW) \\
\hline Diesel & 4.70 & 1.25 & 1.58 & 1.87 \\
E15B35D50 & 4.74 & 1.25 & 1.45 & 2.04 \\
E15B35FTD50 & 4.75 & 1.25 & 1.59 & 1.92 \\
\hline
\end{tabular}

The rate of energy inlet from the fuel is mainly related to the LHV and the combustion efficiency of the fuel. The inlet fuel energy increased when the engine was fueled with the E15B35FTD50 blend compared with diesel. In order to maintain the same IMEP, when the engine was fueled with different fuels, more fuel was consumed for E15B35FTD50 (10.8\% in mass) mainly due to the lower LHV (9.8\%) of the blend in comparison with diesel fuel, as shown in Table 2. As for the E15B35D50 blend, the mass fuel consumption was increased by $11.8 \%$ and the LHV decreased by $8.7 \%$ when compared with diesel. In comparison with the E15B35D50 blend, the blend of ethanol and F-T diesel (E15B35FTD50) presented a slight difference in the LHV value of approximately $1 \%$. Previous researchers had reported similar results and found an increase in the fuel energy rate whilst the energy efficiency decreased $[27,66]$, because of the difference in the LHV of the tested fuels compared to the baseline diesel.

The small variation in the energy outlet rate by exhaust gases for the evaluated fuels could be explained due to the differences in the engine-outlet exhaust gas temperature and emissions. The measured exhaust gas temperature ranged around $234-240{ }^{\circ} \mathrm{C}$ for diesel, 230-234 ${ }^{\circ} \mathrm{C}$ for E15B35D50, and $232-235^{\circ} \mathrm{C}$ for E15B35FTD50. The addition of ethanol to F-T diesel and biodiesel (E15B35FTD50) caused a decrease in the exhaust temperature of the engine probably due to the alcohol cooling effect related to the higher heat of evaporation. Previous works have reported similar results of combustion temperature decrease by adding ethanol to diesel or biodiesel [67]. In addition, as the exhaust energy is directly 
related to the engine output emissions, the slightly higher emissions for E15B35FTD50 of some measured species have influenced the exhaust energy rate. Although, for the blend E15B35D50 the exhaust energy rate of the blend was mainly affected by the lower $\mathrm{CO}_{2}$ amount in the exhaust and presented the lowest value among the tested fuels. Nevertheless, the released amount of energy rate in the exhaust might be partially recovered and thus enhance the energy efficiency [68]. Moreover, other losses such as the heat transfers from the cylinder walls and by the coolant were merged to simplify the control volume.

Figure 5 shows the energy balance of diesel, E15B35D50, and E15B35FTD50. The graph shows that $26.6 \%$ of the inlet fuel energy of diesel fuel was converted to outlet engine work, $33.6 \%$ was discharged in the exhaust gases, whereas the remaining (39.8\%) was computed as energy losses. Similarly, for the combustion of E15B35FTD50, the energy distribution has revealed that $26.2 \%$ of the inlet energy was transformed into outlet work, $33.4 \%$ was lost through exhaust gases, and it can be deduced that $40.3 \%$ of the inlet energy is lost through heat transfer. Similar results were reported by previous works $[69,70]$. Sarıkoç et al. [27] found that the mixture of butanol $(5-20 \% v / v)$, biodiesel $(20 \% v / v)$, and diesel $(60-75 \% v / v)$ resulted in lower outlet work energy and energy efficiency than when using diesel fuel. The researchers stated that the addition of biodiesel and butanol resulted in a reduction in the LHV of the blends, which caused a decrease in energy efficiency. In the present work, the energy balance analysis resulted in the lower energy efficiency of the engine when fueled with E15B35FTD50 as a result of the higher fuel energy rate of the blend in relation to the diesel fuel.

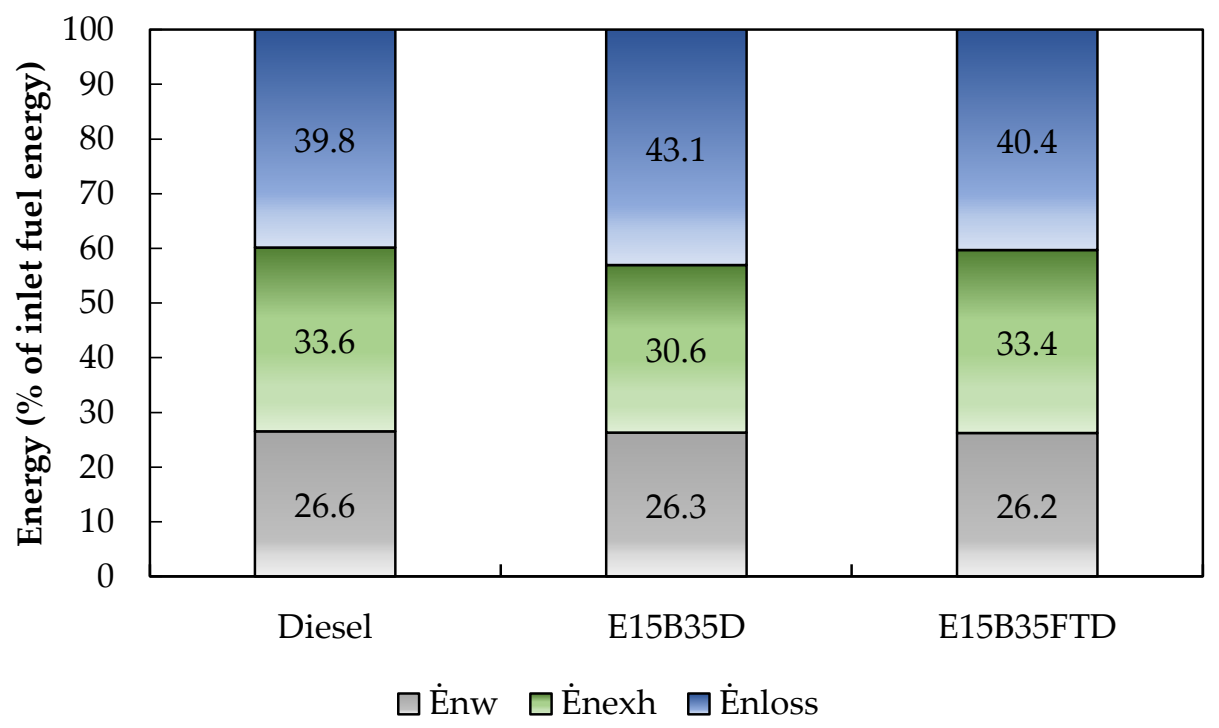

Figure 5. Energy balance of the engine for each tested fuel.

\subsection{Exergy Analysis}

An energy analysis of the engine does not provide enough data to enable the determination of the overall losses and efficiency regarding the engine operation when it is fueled with different fuels. Hence, the exergy analysis complements the thermodynamic analysis of the diesel engine.

The exergy analysis was calculated through the experimental data of the diesel engine based on the used fuel and blends. The inlet fuel exergy rate and the outlet exergy (work outlet exergy, exhaust exergy, exergy loss, and exergy destruction) values were determined by dividing each exergy component by the exergy of the fuel, as given in Table 5 . 
Table 5. Exergy distribution in the engine control volume.

\begin{tabular}{cccccc}
\hline Fuel & $\begin{array}{c}\text { Fuel Exergy } \\
\text { Rate (kW) }\end{array}$ & Work Rate (kW) & $\begin{array}{c}\text { Exhaust Gas Exergy } \\
\text { Rate (kW) }\end{array}$ & $\begin{array}{c}\text { Heat Losses } \\
\text { Rate (kW) }\end{array}$ & $\begin{array}{c}\text { Exergy Destruction } \\
\text { Rate (kW) }\end{array}$ \\
\hline Diesel & 5.01 & 1.25 & 0.28 & 0.29 & 3.20 \\
E15B35D50 & 5.08 & 1.25 & 0.26 & 0.32 & 3.25 \\
E15B35FTD50 & 5.10 & 1.25 & 0.27 & 0.30 & 3.29 \\
\hline
\end{tabular}

The results for the fuel energy and for the fuel exergy rates shown a similar trend for diesel fuel, E15B35D50, and E15B35FTD50, as both are functions of the fuel mass flow rate and their LHV. There was an increase in the fuel exergy when the diesel engine was fueled with the E15B35FTD50 blend in comparison with diesel. Moreover, the inlet exergy rates of the evaluated fuels were increased with respect to the inlet energy rates. The results have shown that the inlet exergy of the tested fuels ranged from $6.7-7.4 \%$ higher in comparison with its respective inlet energy. At the respective engine operational condition, the fuel exergy rates for diesel, E15B35D50, and E15B35FTD50 were found to be in the range of 5.01-5.10 kW, respectively. The higher value for the E15B35FTD50 blend is attributed to the increased fuel consumption compared to the engine fueled with diesel fuel, which was required to maintain the same indicated power. These findings are in agreement with previous works in the literature using blends of biofuels [29]. Paul et al. [30] reported this behavior is attributed to the increase in fuel consumption, as a result of the decrease in the LHV and an opposite relation between the fuel inlet exergy and the exergy efficiency.

The exergy outlet rate within the exhaust gases has slightly decreased when the engine was fueled with the biofuels in the blends. This is because the higher the exhaust gas temperature, the higher is the exhaust gas exergy rate [47]. In the present work, the exhaust gas temperature decreased for the combustion of the E15B35D50 and E15B35FTD50 blends compared to diesel. A similar result was reported by Kul and Kahraman [26]. Their research reported that the exhaust exergy was affected by the exhaust gas temperature and that the latter was slightly higher for diesel fuel than for the tested blends of diesel/biodiesel/ethanol. The lost exergy rate through the exhaust gases has decreased by $3.8 \%$ for E15B35D50 and 1.9\% E15B35FTD50 blends, respectively. Moreover, the exergy loss rates of the tested fuels were determined as $0.29-0.32 \mathrm{~kW}$. The other exergy losses have shown a similar trend with the energy losses, whereas the E15B35FTD50 blend presented a higher value than diesel fuel.

The exergy destruction rate or irreversibility rate indicates the rate of the available work, which is destroyed due to irreversible processes that occur in the control volume [22]. It is observed that the exergy destruction of the E15B35FTD50 and E15B35D50 blends were found to be respectively $2.4 \%$ and $1.8 \%$ higher than for the diesel fuel. Previous investigations have reported that the addition of biodiesel to diesel increases the exergy destruction rate of the blends in comparison with pure diesel [25]. Sarıkoç et al. [27] obtained lower values of exergy destruction rate with diesel/biodiesel/butanol blends rather than with diesel fuel. The researchers have attributed this result to the decrease in the combustion temperature promoted by the alcohol addition, although the pure biodiesel fuel and the diesel/biodiesel blend had lower values than the ternary blends.

The entropy generation assists in comprehending the system irreversibilities, by supporting the evaluation of the thermal performance of combustion engines [66]. The irreversibility in a system results in entropy generation, which is directly related to the exergy destruction rate. At the evaluated engine condition, the entropy generation of diesel, E15B35D50, and E15B35FTD50 were respectively 0.0107, 0.0109, and $0.0110 \mathrm{~kW} / \mathrm{K}$ (as shown in Figure 6). This could be partially explained by the higher mechanical friction at lower engine loads, as previously reported in [69], which is the major thermodynamic irreversibility of combustion engines. However, the friction losses were not covered within this work. Moreover, it has been reported that higher fuel consumption, as well as the combustion process itself, lead to more irreversibilities [27]. Kavitha et al. [32] have reported that the exergy destruction rate was higher with diesel fuel than with 
diesel/biodiesel/ethanol blends, and thus the entropy generated increased. However, Kul and Kahraman [26] have found higher exergy destruction rates for $8-25 \%(v / v)$ of biofuels (biodiesel/ethanol) blended with a diesel under the same experimental engine operating condition, when compared to reference diesel. This can be explained by the difference between the injection systems (common-rail or conventional injection system) used in this research, which affects the timing that the fuel is injected, as it varies with the compressibility of the fuel, and the ignition time, which varies with the cetane number of the fuel blend. Furthermore, as shown in Equations (11) and (12), the term $\varphi$ is directly proportional to the loss (i.e., higher $\varphi$ leads to higher losses) and $\varphi$ is higher in the blends, because of the increased fuel mass fractions of $c, h$, and $o$.

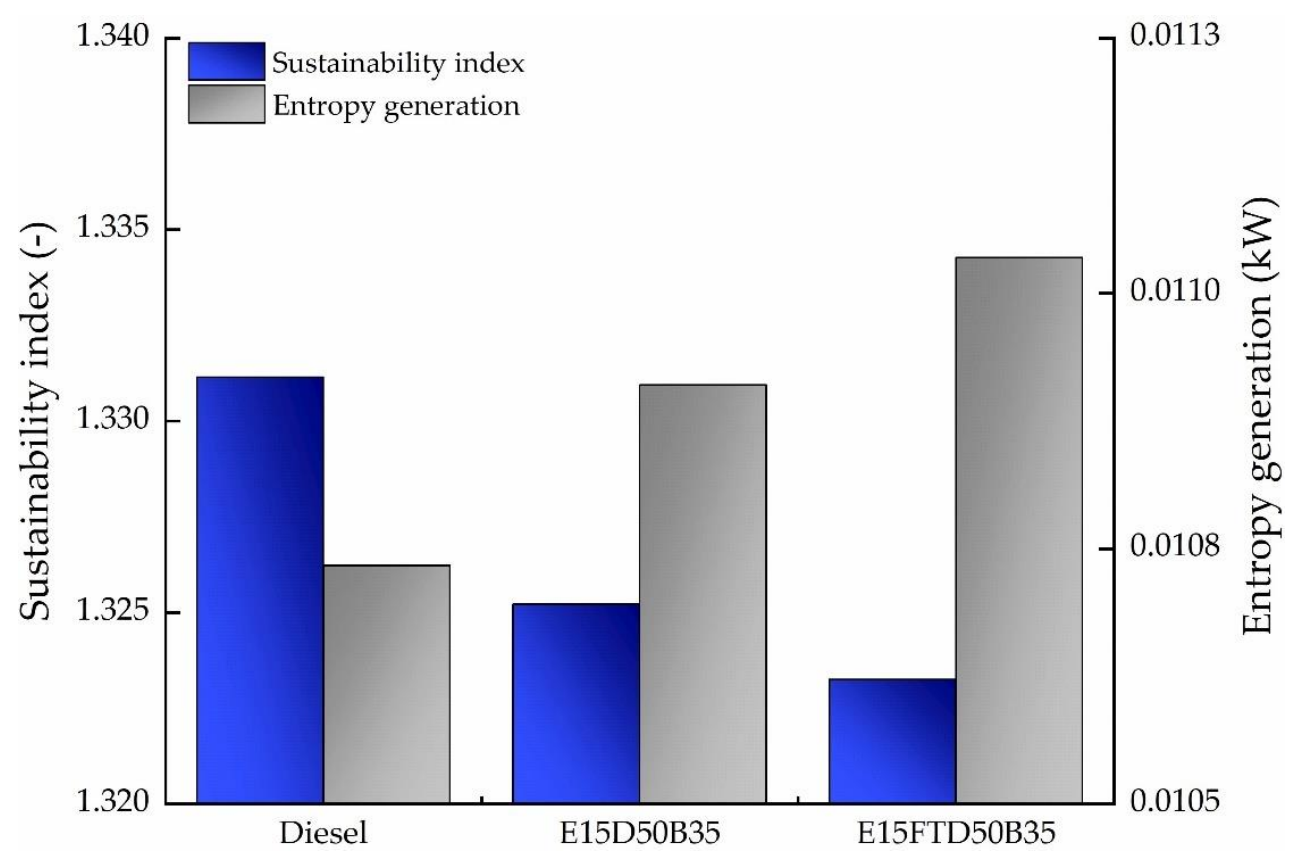

Figure 6. Sustainability index (SI) and entropy generation $\left(\dot{S}_{g e n}\right)$ values of the tested fuels.

The sustainability index is directly proportional to the exergy efficiency of the control volume. It has been observed that the diesel fuel presented more sustainable characteristics in comparison to the E15B35FTD50 blend. The SI values presented in Figure 6 were calculated to be 1.331 for diesel fuel, 1.325 for E15B35D50, and 1.323 for E15B35FTD50. It has been previously reported by Şanli [71] that that pure diesel had higher SI than biodiesel. The researcher discussed that the SI is directly related to the exergy efficiency and that this efficiency was higher for the diesel than for the biodiesel because the LHV of the diesel was greater than that of biodiesel.

Similar to the energy analysis, the exergy balance of each tested fuel was determined based on the inlet fuel exergy. Thus, the exergy balance of diesel, E15B35D50, and E15B35FTD50 are shown in Figure 7. The graph shows that $24.4 \%$ of the available inlet fuel exergy of E15B35FTD50 was used in the form of work, 5.3\%, was discharged within the exhaust gases, $5.8 \%$ was computed as energy losses, while $63.8 \%$ was destroyed. It is clear that the exergy destruction rate represents the major fraction of the exergetic balance in the combustion engine, which is due to the irreversibilities. However, it is possible to use part of the exergy from the exhaust gases. It has been previously recognized in the literature that combustion is the major source of irreversibility inside the ICE cylinder [47,72]. Hoseinpour et al. [69] stated that the fuel type does not show an apparent effect on the exergy losses or irreversibilities in the engine. The researchers argued that this could be due to the many variables that affect the irreversibilities. Moreover, Şanli and Uludamar [73] have reported that only a slight difference was observed among the destruction exergy rate of the different 
biodiesels with respect to diesel fuel and also concluded that the fuel type was not effective on the irreversibilities fraction.

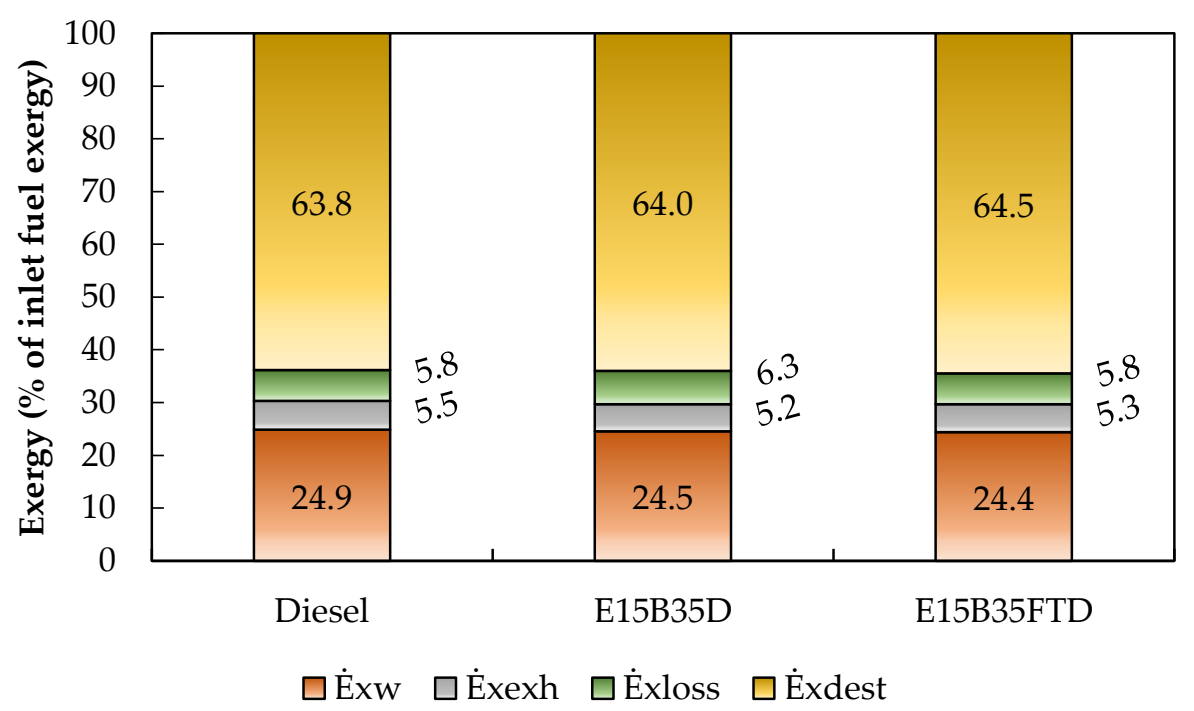

Figure 7. Exergy balance of the engine for each tested fuel.

The comparison between the energy and exergy efficiency (i.e., energy and exergy outlet work) shown in Figure 8a-e demonstrates that both efficiencies had similar findings, approximately $26 \%$, and $24 \%$, respectively, with a small variation between them. The exergy efficiencies were slightly lower than the corresponding energy efficiency. This is a consequence of the different chemical exergy of the tested fuels $(\varphi)$, as shown in Equations (11) and (12). The specific chemical exergy is higher than the LHV of the tested fuels. Thus, the total inlet exergy is always greater than the total inlet fuel energy, which relies on the fuel volumetric fractions (i.e., fuel blend proportions). As a result, the exergy efficiency is always slightly lower for fuel than the corresponding energy efficiency [47]. Moreover, Hoseinpour et al. [69] stated that this decrease in the exergy efficiency is because of the exergy destruction during the combustion of the fuel. It was observed that the addition of the biofuels (ethanol and biodiesel) to diesel fuel reduced both energy and exergy efficiencies, while the substitution to F-T diesel has also slightly reduced both efficiencies. This result is in agreement with the findings of Kul and Kahraman [26] utilizing blends of diesel/biodiesel/ethanol and Sarıkoç et al. [27] with diesel/biodiesel/butanol, as compared with results using diesel fuel.

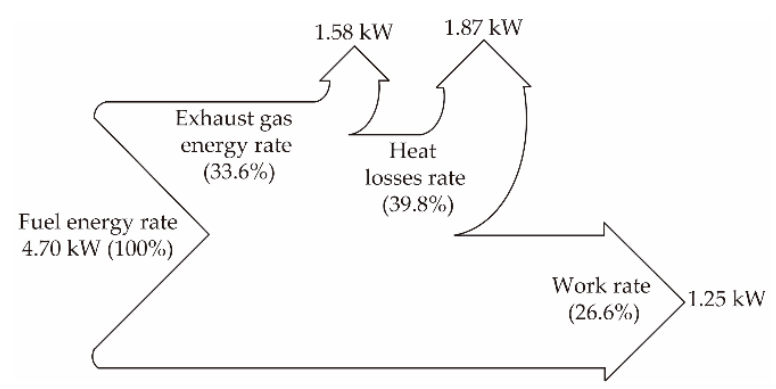

(a)

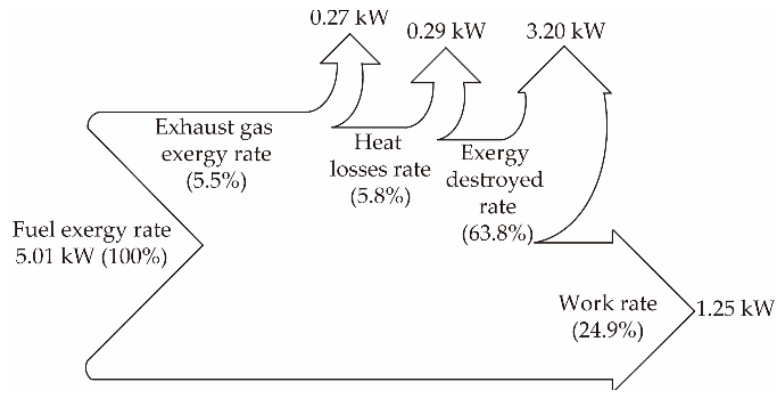

(b)

Figure 8. Cont. 


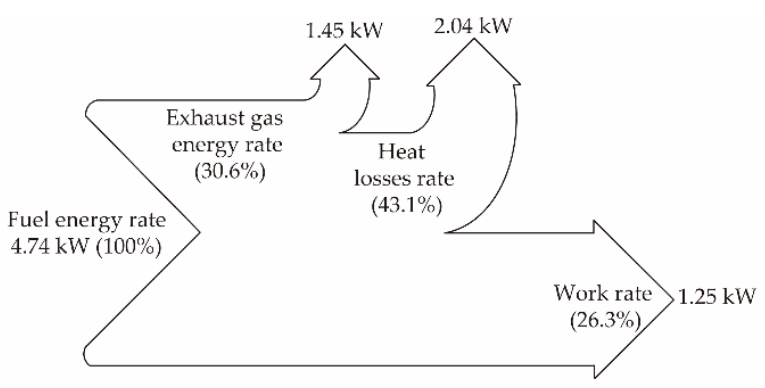

(c)

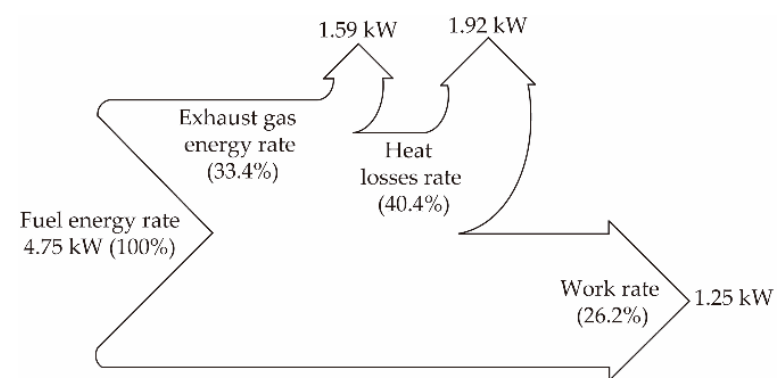

(e)

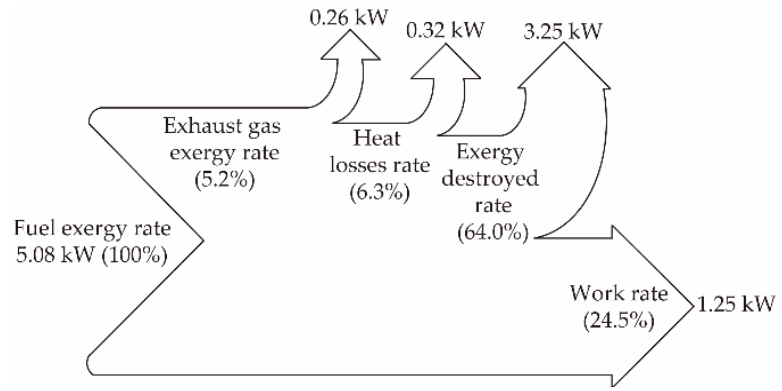

(d)

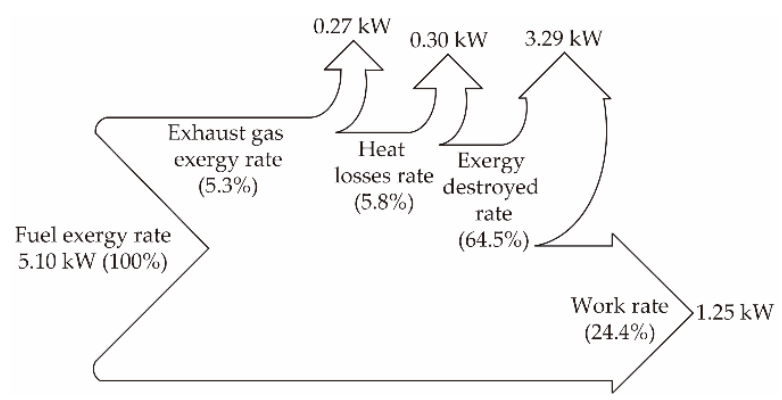

(f)

Figure 8. Energy flow (Sankey) diagrams on the left side and exergy flow (Grossman) diagrams on the right side showing the comparison of energy and exergy efficiencies of the engine fueled with (a,b) diesel; (c,d) E15B35D50; (e,f) E15B35FTD50.

Table 6 shows the summary of the energy and exergy efficiencies of the current work. The comparison of the present results with those by previous researchers, presented in Table 1, for different fuel types and engine operating conditions were either lower, nearly the same, or higher than that of the current work. The main reasons for the difference in these results are the fuel type, blend composition, and properties (e.g., cetane number, heating value, etc.) and the experimental conditions at which the diesel engines were evaluated.

Table 6. Summary of the energy and exergy results of this work.

\begin{tabular}{ccccc}
\hline $\begin{array}{c}\text { Engine } \\
\text { Characteristics }\end{array}$ & $\begin{array}{c}\text { Operating } \\
\text { Conditions }\end{array}$ & Fuel Type & $\begin{array}{c}\text { Energy } \\
\text { Efficiency (\%) }\end{array}$ & $\begin{array}{c}\text { Exergy } \\
\text { Efficiency (\%) }\end{array}$ \\
\hline $\begin{array}{c}1 \text {-cylinder } \\
4 \text { stroke }\end{array}$ & $\begin{array}{c}\text { 1500 rpm } \\
\text { 2 bar IMEP (30\% load) }\end{array}$ & $\begin{array}{c}\text { Diesel } \\
\text { E15/B35/D50 } \\
\text { E15/B35/FTD50 }\end{array}$ & $26.2-26.6$ & $24.4-24.9$ \\
\hline
\end{tabular}

D: diesel fuel, B: biodiesel fuel, E: ethanol fuel, FTD: Fischer-Tropsch diesel fuel.

\section{Conclusions}

An investigation of the effects of alternative fuel blends (15\% ethanol, $35 \%$ biodiesel, $50 \%$ diesel, E15B35D50, and 15\% ethanol, 35\% biodiesel, 50\% F-T diesel, E15B35FTD50) on the energy and exergy analysis and exhaust emissions was performed. This work extended the understanding regarding the energetic and exergetic performance of synthesized diesellike fuels and biofuels (ethanol and biodiesel) as well as the exhaust emissions from the combustion of alternative fuels.

The energy and the exergy efficiencies were found to be similar, around $26 \%$ and $24 \%$, respectively, with a little difference. The energy efficiency and also exergy efficiency of the diesel engine fueled with F-T diesel and ethanol/biodiesel (E15B35FTD50) was slightly lower than for the diesel fuel as a result of the inlet fuel energy and the higher fuel chemical exergy of the blend, respectively. The major cause of the inefficiency of the engine was the destroyed exergy caused by the irreversibilities of the system, especially by the combustion 
process. The exergy losses from exhaust gases and from the sum of the other losses also contributed to a decrease in the efficiency of the engine. Besides, it could be concluded that the sustainability index of the diesel fuel was higher than for the blends.

The combustion of the fuel blends containing the biofuels (ethanol and biodiesel) produced lower levels of exhaust emissions such as $\mathrm{HC}, \mathrm{NO}, \mathrm{NH}_{3}$, and $\mathrm{N}_{2} \mathrm{O}$ compared to diesel fuel, however with a penalty on the $\mathrm{CO}$ emissions. Overall, the utilization of synthetic F-T diesel and biofuels such as ethanol and biodiesel can effectively mitigate the engine-out emissions, resulting in a similar efficiency of the engine. Thus, these alternative fuels that may be used without requiring modifications to the engine can also contribute to the reduction of fossil diesel utilization. These findings will be beneficial for biofuel and diesel hybrid electric vehicle synergies to achieve emission regulations by 2050 . Besides, only limited literature evaluated the effects of the utilization of F-T diesel, ethanol, and biodiesel on the engine emissions without in-depth engine calibration. Furthermore, none included the light hydrocarbons speciation and unregulated emissions, such as $\mathrm{NH}_{3}$ and formaldehyde. Due to the compatibility of advanced combustion strategies (i.e., RCCI and GCI) in hybrid electric vehicles, it is suggested that future research investigate the performance of ethanol and FT-diesel as well as higher chain alcohols (i.e., butanol and pentanol). Butanol and pentanol provide better miscibility as blended with FT-diesel. Additionally, investigation of advance combustion strategies of alternative fuels with aftertreatment systems can fasten hybridization.

Author Contributions: Conceptualization, F.A.T., O.D., J.M.H. and A.T.; methodology, F.A.T., O.D. and J.M.H.; formal analysis, F.A.T., O.D. and R.L.; investigation, F.A.T., O.D., R.L. and R.P.; resources, A.T.; writing—original draft preparation, F.A.T.; writing—review and editing, O.D., J.M.H., A.T., J.M. and S.A.B.V.d.M.; supervision, A.T., J.M. and S.A.B.V.d.M.; project administration, S.A.B.V.d.M.; funding acquisition, S.A.B.V.d.M. All authors have read and agreed to the published version of the manuscript.

Funding: This research received no external funding.

Institutional Review Board Statement: Not applicable.

Informed Consent Statement: Not applicable.

Data Availability Statement: Not applicable.

Acknowledgments: F.A.T. gratefully acknowledges the managers and researchers of the Future Engines \& Fuels Laboratory of the University of Birmingham for the kind assistance, technical support, lab facilities, and reviews during the hosted research period of time. The Coordenação de Aperfeiçoamento de Pessoal de Nível Superior-Brasil (CAPES)-Finance Code 001 is also acknowledged for the scholarship (No. 88887.199341/2018-00) to pursue F.A.T. postgraduate studies under the International Cooperation Program with the University of Birmingham and CAPES (Ref. 40/2014).

Conflicts of Interest: The authors declare no conflict of interest.

$\begin{array}{ll}\text { Abbreviations } & \\ \text { BTL } & \text { Biomass-to-liquid } \\ \text { bTDC } & \text { Before the top dead center } \\ \mathrm{C}_{2} \mathrm{H}_{2} & \text { Acetylene } \\ \mathrm{C}_{2} \mathrm{H}_{4} & \text { Ethylene } \\ \mathrm{C}_{2} \mathrm{H}_{6} & \text { Ethane } \\ \mathrm{C}_{3} \mathrm{H}_{6} & \text { Propylene } \\ \mathrm{C}_{3} \mathrm{H}_{8} & \text { Propane } \\ \mathrm{CH}_{2} \mathrm{O} & \text { Formaldehyde } \\ \mathrm{CH}_{4} & \text { Methane } \\ \mathrm{CI} & \text { Compression ignition } \\ \mathrm{CO} & \text { Carbon monoxide } \\ \mathrm{CO}_{2} & \text { Carbon dioxide }\end{array}$


E15B35D50

E15B35FTD50

FID

F-T

FTD

FTIR

GTL

$\mathrm{HC}$

HEV

ICE

IMEP

LHV

$\mathrm{N}_{2} \mathrm{O}$

$\mathrm{NH}_{3}$

$\mathrm{NO}$

$\mathrm{NO}_{2}$

$\mathrm{NO}_{\mathrm{x}}$

PCIS

PM

RCCI

SI

TDC

THC

Symbols

$\dot{E} n$

$\dot{E} x$

ex

$h$

$\dot{m}$

$\dot{n}$

$N$

$n_{R}$

$\mathrm{P}$

$\mathrm{T}$

$V_{d}$

$R$

$S$

$\dot{S}$

$x$

\section{Subscripts}

0

ch

cool

dest

exh

gen

i

in

out

ph

W

Greek sumbols
$15 \%$ ethanol, $35 \%$ biodiesel, $50 \%$ diesel

15\% ethanol, 35\% biodiesel, 50\% Fischer-Tropsch diesel

Flame ionization detector

Fischer-Tropsch

Fischer-Tropsch diesel

Fourier transform infrared

Gas-to-liquid

Hydrocarbons

Hybrid electric vehicles

Internal combustion engines

Indicated mean effective pressure

Lower heating value

Nitrous oxide

Ammonia

Nitrogen oxige

Nitrogen dioxide

Nitrogen oxides

Pre-chamber ignition system

Particulate matter

Reactivity-controlled compression ignition

Sustainability index

Top dead center

Total hydrocarbons

energy rate, $\mathrm{W}$

exergy rate, $W$

specific exergy, $\mathrm{J} / \mathrm{kg}$ or $\mathrm{J} / \mathrm{mol}$

enthalpy, $\mathrm{J} / \mathrm{kg}$ or $\mathrm{J} / \mathrm{mol}$

mass flow rate, $\mathrm{kg} / \mathrm{s}$

molar flow rate, $\mathrm{mol} / \mathrm{s}$

engine speed, rpm

number of crank revolutions for each power stroke per cylinder, -

absolute pressure, $\mathrm{Pa}$

temperature, ${ }^{\circ} \mathrm{C}$ or $\mathrm{K}$

displaced volume, $\mathrm{m}^{3}$

universal gas constant, $\mathrm{J} / \mathrm{kg} \cdot \mathrm{K}$ or J $/ \mathrm{mol} \cdot \mathrm{K}$

entropy, $\mathrm{J} / \mathrm{kg} \cdot \mathrm{K}$ or $\mathrm{J} / \mathrm{mol} \cdot \mathrm{K}$

Entropy rate, $\mathrm{W}$

molar fraction, -

reference state

chemical

coolant

destruction

exhaust

generation

individual gaseous species

inlet

outlet

physical

work

activity coefficiency, -

standard chemical exergy, $\mathrm{J} / \mathrm{mol}$

energy efficiency, -

chemical exergy factor, -

exergy efficiency, - 


\section{References}

1. Correa, G.; Muñoz, P.M.; Rodriguez, C.R. A Comparative Energy and Environmental Analysis of a Diesel, Hybrid, Hydrogen and Electric Urban Bus. Energy 2019, 187, 115906. [CrossRef]

2. Serrano, J.R.; Novella, R.; Piqueras, P. Why the Development of Internal Combustion Engines Is Still Necessary to Fight against Global Climate Change from the Perspective of Transportation. Appl. Sci. 2019, 9, 4597. [CrossRef]

3. Dranka, G.G.; Ferreira, P. Electric Vehicles and Biofuels Synergies in the Brazilian Energy System. Energies 2020, $13,4423$. [CrossRef]

4. Paredes Rojas, J.C.; Torres San Miguel, C.R.; Vázquez Medina, R.; Leal Naranjo, J.A.; Ortiz Hernàndez, F.E.; Costa Castelló, R. Pollutant Emissions and Combustion Efficiency Assessment of Engines Using Biodiesel. Appl. Sci. 2020, 10, 8646. [CrossRef]

5. Beatrice, C.; Denbratt, I.; Di Blasio, G.; Di Luca, G.; Ianniello, R.; Saccullo, M. Experimental Assessment on Exploiting Low Carbon Ethanol Fuel in a Light-Duty Dual-Fuel Compression Ignition Engine. Appl. Sci. 2020, 10, 7182. [CrossRef]

6. Shi, J.; Wang, T.; Zhao, Z.; Wu, Z.; Zhang, Z. Cycle-to-Cycle Variation of a Diesel Engine Fueled with Fischer-Tropsch Fuel Synthesized from Coal. Appl. Sci. 2019, 9, 2032. [CrossRef]

7. Mahmoudi, H.; Jahangiri, H.; Doustdar, O.; Akbari, N.; Wood, J.; Tsolakis, A.; Wyszynski, M.L. Maximizing Paraffin to Olefin Ratio Employing Simulated Nitrogen-Rich Syngas via Fischer-Tropsch Process over $\mathrm{Co}_{3} \mathrm{O}_{4} / \mathrm{SiO}_{2}$ Catalysts. Fuel Process. Technol. 2020, 208, 106477. [CrossRef]

8. OECD/FAO. OECD-FAO Agricultural Outlook 2019-2028; OECD: Paris, France, 2019.

9. Çelebi, Y.; Aydın, H. An Overview on the Light Alcohol Fuels in Diesel Engines. Fuel 2019, 236, 890-911. [CrossRef]

10. Mendes Guedes, A.D.; Leal Braga, S.; Pradelle, F. Performance and Combustion Characteristics of a Compression Ignition Engine Running on Diesel-Biodiesel-Ethanol (DBE) Blends-Part 2: Optimization of Injection Timing. Fuel 2018, 225, 174-183. [CrossRef]

11. Emiroğlu, A.O.; Şen, M. Combustion, Performance and Exhaust Emission Characterizations of a Diesel Engine Operating with a Ternary Blend (Alcohol-Biodiesel-Diesel Fuel). Appl. Therm. Eng. 2018, 133, 371-380. [CrossRef]

12. Valencia Ochoa, G.; Acevedo Peñaloza, C.; Duarte Forero, J. Combustion and Performance Study of Low-Displacement Compression Ignition Engines Operating with Diesel-Biodiesel Blends. Appl. Sci. 2020, 10, 907. [CrossRef]

13. Choi, K.; Park, S.; Roh, H.G.; Lee, C.S. Combustion and Emission Reduction Characteristics of GTL-Biodiesel Fuel in a SingleCylinder Diesel Engine. Energies 2019, 12, 2201. [CrossRef]

14. Venu, H.; Raju, V.D.; Lingesan, S.; Soudagar, M.E.M. Influence of $\mathrm{Al}_{2} \mathrm{O}_{3}$ nano Additives in Ternary Fuel (Diesel-Biodiesel-Ethanol) Blends Operated in a Single Cylinder Diesel Engine: Performance, Combustion and Emission Characteristics. Energy 2021, 215, 119091. [CrossRef]

15. Glensor, K.; Muñoz B., M.R. Life-Cycle Assessment of Brazilian Transport Biofuel and Electrification Pathways. Sustainability 2019, 11, 6332. [CrossRef]

16. García, A.; Monsalve-Serrano, J.; Martínez-Boggio, S.; Roso, V.R.; Santos, N.D.S.A. Potential of Bio-Ethanol in Different Advanced Combustion Modes for Hybrid Passenger Vehicles. Renew. Energy 2020, 150, 58-77. [CrossRef]

17. García, A.; Monsalve-Serrano, J. Analysis of a Series Hybrid Vehicle Concept That Combines Low Temperature Combustion and Biofuels as Power Source. Results Eng. 2019, 1, 100001. [CrossRef]

18. Kumar, P.; Sandhu, S.S. Impact Analysis of Partially Premixed Combustion Strategy on the Emissions of a Compression Ignition Engine Fueled with Higher Octane Number Fuels: A Review. Mater. Today Proc. 2021, 45, 5772-5777. [CrossRef]

19. Macián, V.; Monsalve-Serrano, J.; Villalta, D.; Fogué-Robles, Á. Extending the Potential of the Dual-Mode Dual-Fuel Combustion towards the Prospective EURO VII Emissions Limits Using Gasoline and OMEx. Energy Convers. Manag. 2021, $233,113927$. [CrossRef]

20. di Blasio, G.; Vassallo, A.; Pesce, F.C.; Beatrice, C.; Belgiorno, G.; Avolio, G. The Key Role of Advanced, Flexible Fuel Injection Systems to Match the Future $\mathrm{CO}_{2}$ Targets in an Ultra-Light Mid-Size Diesel Engine. SAE Int. J. Engines 2019, 12, 129-144. [CrossRef]

21. Yesilyurt, M.K.; Arslan, M. Analysis of the Fuel Injection Pressure Effects on Energy and Exergy Efficiencies of a Diesel Engine Operating with Biodiesel. Biofuels 2019, 10, 643-655. [CrossRef]

22. da Silva, J.A.M.; Seifert, V.; de Morais, V.O.B.; Tsolakis, A.; Herreros, J.; Torres, E. Exergy Evaluation and ORC Use as an Alternative for Efficiency Improvement in a CI-Engine Power Plant. Sustain. Energy Technol. Assess. 2018, 30, 216-223. [CrossRef]

23. Sun, W.; Liu, Z. Parametric Assessment on the Advanced Exergy Performance of a $\mathrm{CO}_{2}$ Energy Storage Based Trigeneration System. Appl. Sci. 2020, 10, 8341. [CrossRef]

24. Dogan, B.; Cakmak, A.; Yesilyurt, M.K.; Erol, D. Investigation on 1-Heptanol as an Oxygenated Additive with Diesel Fuel for Compression-Ignition Engine Applications: An Approach in Terms of Energy, Exergy, Exergoeconomic, Enviroeconomic, and Sustainability Analyses. Fuel 2020, 275, 117973. [CrossRef]

25. Karagoz, M.; Uysal, C.; Agbulut, U.; Saridemir, S. Exergetic and Exergoeconomic Analyses of a CI Engine Fueled with DieselBiodiesel Blends Containing Various Metal-Oxide Nanoparticles. Energy 2021, 214, 118830. [CrossRef]

26. Kul, B.S.; Kahraman, A. Energy and Exergy Analyses of a Diesel Engine Fuelled with Biodiesel-Diesel Blends Containing 5\% Bioethanol. Entropy 2016, 18, 387. [CrossRef]

27. Sarıkoç, S.; Örs, İ.; Ünalan, S. An Experimental Study on Energy-Exergy Analysis and Sustainability Index in a Diesel Engine with Direct Injection Diesel-Biodiesel-Butanol Fuel Blends. Fuel 2020, 268, 117321. [CrossRef] 
28. Fayad, M.A.; Fernàndez-Rodríguez, D.; Herreros, J.M.; Lapuerta, M.; Tsolakis, A. Interactions between Aftertreatment Systems Architecture and Combustion of Oxygenated Fuels for Improved Low Temperature Catalysts Activity. Fuel 2018, 229, 189-197. [CrossRef]

29. Khoobbakht, G.; Akram, A.; Karimi, M.; Najafi, G. Exergy and Energy Analysis of Combustion of Blended Levels of Biodiesel, Ethanol and Diesel Fuel in a DI Diesel Engine. Appl. Therm. Eng. 2016, 99, 720-729. [CrossRef]

30. Paul, A.; Panua, R.; Debroy, D. An Experimental Study of Combustion, Performance, Exergy and Emission Characteristics of a CI Engine Fueled by Diesel-Ethanol-Biodiesel Blends. Energy 2017, 141, 839-852. [CrossRef]

31. Krishna, S.M.; Abdul Salam, P.; Tongroon, M.; Chollacoop, N. Performance and Emission Assessment of Optimally Blended Biodiesel-Diesel-Ethanol in Diesel Engine Generator. Appl. Therm. Eng. 2019, 155, 525-533. [CrossRef]

32. Kavitha, K.R.; Jayaprabakar, J.; Prabhu, A. Exergy and Energy Analyses on Biodiesel-Diesel-Ethanol Blends in a Diesel Engine. Int. J. Ambient. Energy 2019, 0750, 1-5. [CrossRef]

33. Nabi, M.N.; Hustad, J.E.; Arefin, M.A. The Influence of Fischer-Tropsch-Biodiesel-Diesel Blends on Energy and Exergy Parameters in a Six-Cylinder Turbocharged Diesel Engine. Energy Rep. 2020, 6, 832-840. [CrossRef]

34. Ferreira, V.P.; Torres, E.A.; da Silva, J.A.M.; Silva, L.F. Evaluation of Ethanol as Additive for NOx and PM Reduction in CI Engines Fueled with Diesel-Biodiesel Blends Using a Pump Assembly. J. Braz. Soc. Mech. Sci. Eng. 2020, 42, 408. [CrossRef]

35. Fayad, M.A.; Tsolakis, A.; Martos, F.J. Influence of Alternative Fuels on Combustion and Characteristics of Particulate Matter Morphology in a Compression Ignition Diesel Engine. Renew. Energy 2020, 149, 962-969. [CrossRef]

36. Fayad, M.A.; Herreros, J.M.; Martos, F.J.; Tsolakis, A. Role of Alternative Fuels on Particulate Matter (PM) Characteristics and Influence of the Diesel Oxidation Catalyst. Environ. Sci. Technol. 2015, 49, 11967-11973. [CrossRef]

37. Soloiu, V.; Gaubert, R.; Moncada, J.; Wiley, J.; Williams, J.; Harp, S.; Ilie, M.; Molina, G.; Mothershed, D. Reactivity Controlled Compression Ignition and Low Temperature Combustion of Fischer-Tropsch Fuel Blended with n-Butanol. Renew. Energy 2019, 134, 1173-1189. [CrossRef]

38. Herreros, J.M.; Schroer, K.; Sukjit, E.; Tsolakis, A. Extending the Environmental Benefits of Ethanol-Diesel Blends through DGE Incorporation. Appl. Energy 2015, 146, 335-343. [CrossRef]

39. Serhan, N.; Tsolakis, A.; Wahbi, A.; Martos, F.J.; Golunski, S. Modifying Catalytically the Soot Morphology and Nanostructure in Diesel Exhaust: Influence of Silver De-NOx Catalyst $\left(\mathrm{Ag} / \mathrm{Al}_{2} \mathrm{O}_{3}\right)$. Appl. Catal. B Environ. 2019, 241, 471-482. [CrossRef]

40. Moran, M.J.; Shapiro, H.N.; Boettner, D.D.; Bailey, M.B. Fundamentals of Engineering Thermodynamics, 9th ed.; Wiley: Hoboken, NJ, USA, 2018; ISBN 978-1-119-39138-8.

41. Kotas, T.J. The Exergy Method of Thermal Plant Analysis; Elsevier: Amsterdam, The Netherlands, 1985; ISBN 0-408-01350-8.

42. Szargut, J. Exergy Method: Technical and Ecological Applications; WIT Press: Southampton, UK, 2005; ISBN 978-1-85312-753-3.

43. Dincer, I.; Bicer, Y. Exergy: Energy, Environment and Sustainable Development, 2nd ed.; Elsevier Science: Amsterdam, The Netherlands, 2013; ISBN 978-0-08-097089-9.

44. Karagoz, M.; Uysal, C.; Agbulut, U.; Saridemir, S. Energy, Exergy, Economic and Sustainability Assessments of a Compression Ignition Diesel Engine Fueled with Tire Pyrolytic Oil-Diesel Blends. J. Clean. Prod. 2020, 264, 121724. [CrossRef]

45. Sayin, C.; Hosoz, M.; Canakci, M.; Kilicaslan, I. Energy and Exergy Analyses of a Gasoline Engine. Int. J. Energy Res. 2007, 31, 259-273. [CrossRef]

46. Caliskan, H.; Mori, K. Environmental, Enviroeconomic and Enhanced Thermodynamic Analyses of a Diesel Engine with Diesel Oxidation Catalyst (DOC) and Diesel Particulate Filter (DPF) after Treatment Systems. Energy 2017, 128, 128-144. [CrossRef]

47. Verma, S.; Das, L.M.; Kaushik, S.C.; Tyagi, S.K. An Experimental Investigation of Exergetic Performance and Emission Characteristics of Hydrogen Supplemented Biogas-Diesel Dual Fuel Engine. Int. J. Hydrogen Energy 2018, 43, 2452-2468. [CrossRef]

48. Tat, M.E. Cetane Number Effect on the Energetic and Exergetic Efficiency of a Diesel Engine Fuelled with Biodiesel. Fuel Process. Technol. 2011, 92, 1311-1321. [CrossRef]

49. Rosen, M.A.; Dincer, I.; Kanoglu, M. Role of Exergy in Increasing Efficiency and Sustainability and Reducing Environmental Impact. Energy Policy 2008, 36, 128-137. [CrossRef]

50. Andrade Torres, F.; Doustdar, O.; Herreros, J.M.; Li, R.; Poku, R.; Tsolakis, A.; Martins, J.; Vieira de Melo, S.A.B. A Comparative Study of Biofuels and Fischer-Tropsch Diesel Blends on the Engine Combustion Performance for Reducing Exhaust Gaseous and Particulate Emissions. Energies 2021, 14, 1538. [CrossRef]

51. Ghadikolaei, M.A.; Cheung, C.S.; Yung, K.-F. Study of Combustion, Performance and Emissions of Diesel Engine Fueled with Diesel/Biodiesel/Alcohol Blends Having the Same Oxygen Concentration. Energy 2018, 157, 258-269. [CrossRef]

52. Carvalho, M.; Torres, F.; Ferreira, V.; Silva, J.; Martins, J.; Torres, E. Effects of Diethyl Ether Introduction in Emissions and Performance of a Diesel Engine Fueled with Biodiesel-Ethanol Blends. Energies 2020, 13, 3787. [CrossRef]

53. Heidari-Maleni, A.; Gundoshmian, T.M.; Karimi, B.; Jahanbakhshi, A.; Ghobadian, B. A Novel Fuel Based on Biocompatible Nanoparticles and Ethanol-Biodiesel Blends to Improve Diesel Engines Performance and Reduce Exhaust Emissions. Fuel 2020, 276, 118079. [CrossRef]

54. Mofijur, M.; Rasul, M.G.; Hyde, J.; Azad, A.K.; Mamat, R.; Bhuiya, M.M.K. Role of Biofuel and Their Binary (Diesel-Biodiesel) and Ternary (Ethanol-Biodiesel-Diesel) Blends on Internal Combustion Engines Emission Reduction. Renew. Sustain. Energy Rev. 2016, 53, 265-278. [CrossRef] 
55. Guarieiro, L.L.N.; de Souza, A.F.; Torres, E.A.; de Andrade, J.B. Emission Profile of 18 Carbonyl Compounds, $\mathrm{CO}_{2} \mathrm{CO}_{2}$, and NOx Emitted by a Diesel Engine Fuelled with Diesel and Ternary Blends Containing Diesel, Ethanol and Biodiesel or Vegetable Oils. Atmos. Environ. 2009, 43, 2754-2761. [CrossRef]

56. de Carvalho, M.A.S.; Achy, A.R.A.; Junior, L.C.S.S.; Ferreira, V.P.; da Silva, J.A.M.; Pepe, I.M.; Torres, E.A. Mechanical and Emissions Performance of a Diesel Engine Fueled with Biodiesel, Ethanol and Diethyl Ether Blends. J. Braz. Soc. Mech. Sci. Eng. 2020, 42, 182. [CrossRef]

57. Khan, M.; Tafreshi, R.; Mokahal, A.J.; Mohamed, M.T.; Hanbal, M.Y.; Elturk, J. Single Cylinder GTL ENGINE: An Experimental Comparison between Traditional Diesel and GTL Diesel on Single Cylinder Engine; SAE Technical Papers; SAE International: Warrendale, PA, USA, 5 April 2016.

58. Gill, S.S.; Tsolakis, A.; Dearn, K.D.; Rodríguez-Fernández, J. Combustion Characteristics and Emissions of Fischer-Tropsch Diesel Fuels in IC Engines. Prog. Energy Combust. Sci. 2011, 37, 503-523. [CrossRef]

59. Soriano, J.A.; García-Contreras, R.; Leiva-Candia, D.; Soto, F. Influence on Performance and Emissions of an Automotive Diesel Engine Fueled with Biodiesel and Paraffinic Fuels: GTL and Biojet Fuel Farnesane. Energy Fuels 2018, 32, 5125-5133. [CrossRef]

60. Ye, L.; Shi, Y.; Liu, T.; Zheng, Q.; Ashfaq, M.M.; Sun, C.; Shi, A.; Ajmal, M. Study on Emission and Particulate Matter Characteristics from Diesel Engine Fueled with N-Pentanol/Fischer-Tropsch Diesel. Energy Sources Part A Recovery Util. Environ. Eff. 2020, 1-17. [CrossRef]

61. de Oliveira, A.; Valente, O.S.; Sodré, J.R. Effects of Ethanol Addition to Biodiesel-Diesel Oil Blends (B7 and B20) on Engine Emissions and Fuel Consumption. MRS Adv. 2017, 2, 4005-4015. [CrossRef]

62. Martins, J.; Torres, F.; Torres, E.; Pimenta, H.; Ferreira, V. The Use of Biodiesel on the Performance and Emission Characteristics of Diesel Engined Vehicles; SAE Technical Papers; SAE International: Warrendale, PA, USA, 2013; Volume 3, pp. 1-8.

63. Gnanamoorthi, V.; Devaradjane, G. Effect of Compression Ratio on the Performance, Combustion and Emission of DI Diesel Engine Fueled with Ethanol-Diesel Blend. J. Energy Inst. 2015, 88, 19-26. [CrossRef]

64. Herreros, J.M.; Gill, S.S.; Lefort, I.; Tsolakis, A.; Millington, P.; Moss, E. Enhancing the Low Temperature Oxidation Performance over a Pt and a Pt-Pd Diesel Oxidation Catalyst. Appl. Catal. B Environ. 2014, 147, 835-841. [CrossRef]

65. Suarez-Bertoa, R.; Mendoza-Villafuerte, P.; Riccobono, F.; Vojtisek, M.; Pechout, M.; Perujo, A.; Astorga, C. On-Road Measurement of NH 3 Emissions from Gasoline and Diesel Passenger Cars during Real World Driving Conditions. Atmos. Environ. 2017, 166, 488-497. [CrossRef]

66. Yesilyurt, M.K. The Examination of a Compression-Ignition Engine Powered by Peanut Oil Biodiesel and Diesel Fuel in Terms of Energetic and Exergetic Performance Parameters. Fuel 2020, 278, 118319. [CrossRef]

67. Tutak, W.; Jamrozik, A.; Pyrc, M.; Sobiepański, M. A Comparative Study of Co-Combustion Process of Diesel-Ethanol and Biodiesel-Ethanol Blends in the Direct Injection Diesel Engine. Appl. Therm. Eng. 2017, 117, 155-163. [CrossRef]

68. Bourhis, G.; Leduc, P. Energy and Exergy Balances for Modern Diesel and Gasoline Engines. Oil Gas Sci. Technol. Rev. De L'institut Français Du Pétrole 2010, 65, 39-46. [CrossRef]

69. Hoseinpour, M.; Sadrnia, H.; Tabasizadeh, M.; Ghobadian, B. Energy and Exergy Analyses of a Diesel Engine Fueled with Diesel, Biodiesel-Diesel Blend and Gasoline Fumigation. Energy 2017, 141, 2408-2420. [CrossRef]

70. Jena, J.; Misra, R.D. Effect of Fuel Oxygen on the Energetic and Exergetic Efficiency of a Compression Ignition Engine Fuelled Separately with Palm and Karanja Biodiesels. Energy 2014, 68, 411-419. [CrossRef]

71. Şanli, B.G. Energetic and Exergetic Performance of a Diesel Engine Fueled with Diesel and Microalgae Biodiesel. Energy Sources Part A Recovery Util. Environ. Eff. 2019, 41, 2519-2533. [CrossRef]

72. Özcan, H. Energy and Exergy Analyses of Al2O3-Diesel-Biodiesel Blends in a Diesel Engine. Int. J. Exergy 2019, 28, 29. [CrossRef]

73. Şanli, B.G.; Uludamar, E. Energy and Exergy Analysis of a Diesel Engine Fuelled with Diesel and Biodiesel Fuels at Various Engine Speeds. Energy Sources Part A Recovery Util. Environ. Eff. 2020, 42, 1299-1313. [CrossRef] 